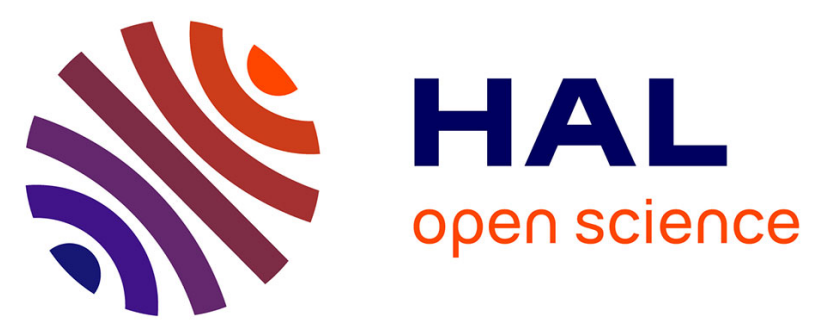

\title{
Insulin and growth hormone-releasing peptide-6 (GHRP-6) have differential beneficial effects on cell turnover in the pituitary, hypothalamus and cerebellum of streptozotocin (STZ)-induced diabetic rats
}

Miriam Granado, Cristina García-Cáceres, María Tuda, Laura M. Frago, Julie

A. Chowen, Jesús Argente

\section{To cite this version:}

Miriam Granado, Cristina García-Cáceres, María Tuda, Laura M. Frago, Julie A. Chowen, et al.. Insulin and growth hormone-releasing peptide-6 (GHRP-6) have differential beneficial effects on cell turnover in the pituitary, hypothalamus and cerebellum of streptozotocin (STZ)-induced diabetic rats. Molecular and Cellular Endocrinology, 2011, 337 (1-2), pp.101. 10.1016/j.mce.2011.02.002 . hal-00685377

\section{HAL Id: hal-00685377 \\ https://hal.science/hal-00685377}

Submitted on 5 Apr 2012

HAL is a multi-disciplinary open access archive for the deposit and dissemination of scientific research documents, whether they are published or not. The documents may come from teaching and research institutions in France or abroad, or from public or private research centers.
L'archive ouverte pluridisciplinaire HAL, est destinée au dépôt et à la diffusion de documents scientifiques de niveau recherche, publiés ou non, émanant des établissements d'enseignement et de recherche français ou étrangers, des laboratoires publics ou privés. 


\section{Accepted Manuscript}

Title: Insulin and growth hormone-releasing peptide- 6 (GHRP-6) have differential beneficial effects on cell turnover in the pituitary, hypothalamus and cerebellum of streptozotocin (STZ)-induced diabetic rats

Authors: Miriam Granado, Cristina García-Cáceres, María

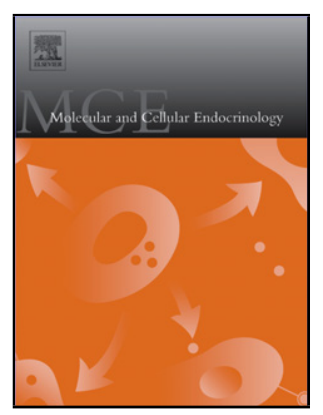

Tuda, Laura M. Frago, Julie A. Chowen, Jesús Argente

PII:

S0303-7207(11)00096-7

DOI: doi:10.1016/j.mce.2011.02.002

Reference: MCE 7765

To appear in: $\quad$ Molecular and Cellular Endocrinology

Received date: $\quad 29-10-2010$

Revised date: $\quad 9-1-2011$

Accepted date: $\quad$ 4-2-2011

Please cite this article as: Granado, M., García-Cáceres, C., Tuda, M., Frago, L.M., Chowen, J.A., Argente, J., Insulin and growth hormone-releasing peptide-6 (GHRP6) have differential beneficial effects on cell turnover in the pituitary, hypothalamus and cerebellum of streptozotocin (STZ)-induced diabetic rats, Molecular and Cellular Endocrinology (2008), doi:10.1016/j.mce.2011.02.002

This is a PDF file of an unedited manuscript that has been accepted for publication. As a service to our customers we are providing this early version of the manuscript. The manuscript will undergo copyediting, typesetting, and review of the resulting proof before it is published in its final form. Please note that during the production process errors may be discovered which could affect the content, and all legal disclaimers that apply to the journal pertain. 


\section{Elsevier Editorial System(tm) for Molecular and Cellular Endocrinology Manuscript Draft}

\section{Manuscript Number: MCE-D-10-00456R1}

Title: Insulin and growth hormone-releasing peptide-6 (GHRP-6) have differential beneficial effects on cell turnover in the pituitary, hypothalamus and cerebellum of streptozotocin (STZ)-induced diabetic rats.

Article Type: Research Paper

Keywords: Diabetes, apoptosis, insulin, GHRP-6, ghrelin, pituitary, hypothalamus, cerebellum.

Corresponding Author: Ph.D. MIRIAM GRANADO, Ph.D.

Corresponding Author's Institution: FACULTAD DE MEDICINA. UNIVERSIDAD AUTÓNOMA DE MADRID

First Author: MIRIAM GRANADO, Ph.D.

Order of Authors: MIRIAM GRANADO, Ph.D.; CRISTINA GARCIA-CACERES, Bs.D.; MARIA TUDA, Bs.D.; LAURA M FRAGO, Ph.D.; JULIE A CHOWEN, Ph.D.; JESUS ARGENTE, M.D., Ph.D.

Abstract: Poorly controlled type 1 diabetes is associated with hormonal imbalances and increased cell death in different tissues, including the pituitary, hypothalamus and cerebellum. In the pituitary, lactotrophs are the cell population with the greatest increase in cell death, whereas in the hypothalamus and cerebellum astrocytes are most highly affected. Insulin treatment can delay, but does not prevent, diabetic complications. As ghrelin and growth hormone (GH) secretagogues are reported to prevent apoptosis in different tissues, and to modulate glucose homeostasis, a combined hormonal treatment may be beneficial. Hence, we analyzed the effect of insulin and GH-releasing peptide 6 (GHRP-6) on diabetes-induced apoptosis in the pituitary, hypothalamus and cerebellum of diabetic rats. Adult male Wistar rats were made diabetic by streptozotocin injection $(65 \mathrm{mg} / \mathrm{kg} \mathrm{ip})$ and divided into four groups from diabetes onset: those receiving a daily sc injection of saline (1 $\mathrm{ml} / \mathrm{kg} /$ day), GHRP-6 (150 $\mu \mathrm{g} / \mathrm{kg} /$ day), insulin (1-8 U/day) or insulin plus GHRP-6 for 8 weeks. Control non-diabetic rats received saline $(1 \mathrm{ml} / \mathrm{kg} /$ day $)$. Diabetes increased cell death in the pituitary, hypothalamus and cerebellum $(\mathrm{P}<0.05)$. In the pituitary, insulin treatment prevented diabetes-induced apoptosis $(\mathrm{P}<0.01)$, as well as the decline in prolactin and GH mRNA levels $(\mathrm{P}<0.05)$. In the hypothalamus, neither insulin nor GHRP- 6 decreased diabetes-induced cell death. However, the combined treatment of insulin+GHRP- 6 prevented the diabetes induced-decrease in glial fibrillary acidic protein (GFAP) levels $(\mathrm{P}<0.05)$. In the cerebellum, although insulin treatment increased GFAP levels $(\mathrm{P}<0.01)$, only the combined treatment of insulin+GHRP-6 decreased diabetes-induced apoptosis $(\mathrm{P}<0.05)$. In conclusion, insulin and GHRP-6 exert tissue specific effects in STZ-diabetic rats and act synergistically on some processes. Indeed, insulin treatment does not seem to be effective on preventing some of the diabetes-induced alterations in the central nervous system. 


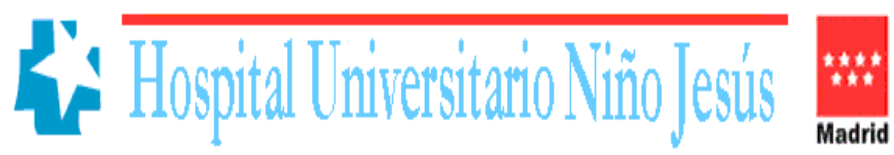

Dear Editor:

You can find attached the revised version of our manuscript entitled "Insulin and growth hormone-releasing peptide-6 (GHRP-6) have differential beneficial effects on cell turnover in the pituitary, hypothalamus and cerebellum of streptozotocin (STZ)-induced diabetic rats", together with the response to the reviewers and the revised figures.

We do hope you reconsider its publication in Molecular and Cellular Endocrinology.

Sincerely,

Dr. Jesús Argente Oliver 
Reviewer \#1: Comments to the Authors:

The authors analyzed the effects of insulin, GHRP-6, and the two in combination, on STZ-induced apoptosis in the pituitary, hypothalamus and cerebellum of diabetic rats.

\section{Major concerns:}

1. The main finding is that only insulin has a protective effect against apoptosis; insulin decreased cell death and increased cell proliferation (PCNA expression). The insulin effect is a known knowledge. The authors undertook to study the effect(s) of GHRP-6, however, the effects of GHRP6 appear to be minimal in most of the experiments. In the reviewer's opinion, the statement that "insulin and GHRP-6 act synergistically" is an overreaching conclusion given the results presented, and the conclusion stated in the title, "The combination of insulin and growth hormonereleasing peptide-6 (GHRP-6) may be beneficial against cell death in the pituitary, hypothalamus and cerebellum of streptozotocin (STZ)-induced diabetic rats", is mostly not supported by the data. The title needs to be rephrased to accurately reflect the main finding of the paper.

We agree with the reviewer that insulin and GHRP-6 do not act synergistically in all areas studied. Indeed, the combined treatment did not improve the anti-apoptotic effect of insulin in the pituitary. However, in the hypothalamus and cerebellum while insulin alone did not have a significant effect, the treatment with insulin+GHRP-6 decreased cell death in these two areas such that they were no longer significantly different from controls. In contrast, insulin treatment increased cell proliferation (PCNA levels) in the pituitary and cerebellum of diabetic rats, but not in the hypothalamus, while GHRP-6 alone also increased PCNA levels in the cerebellum. Thus, both GHRP-6 and insulin had specific effects on these parameters, with some effects like protection against cell death only being significant with the combined treatment. We have changed the title to more clearly reflect these findings.

New title: "Insulin and growth hormone-releasing peptide-6 (GHRP-6) have differential beneficial effects on cell turnover in the pituitary, hypothalamus and cerebellum of streptozotocin (STZ)-induced diabetic rats". 


\section{Varied insulin doses (1-8u/day) were injected into STZ-induced diabetic}

rats. In the reviewer's opinion, 1-8u/day is a huge range, which would affect the statistical validity of the claims made in the paper.

We agree with the referee that some of the effects of insulin (or lack of effects) may be due to the large variations in the doses or glucose levels. Indeed, cell death may also be induced by these variations. However, we selected this protocol because in this study our objective with insulin treatment was to attempt to maintain glucose levels in the most normal physiological levels. For this reason a constant dosage was not used for all animals or even within the same animal daily. Indeed, as the referee knows, a similar protocol is how diabetic patients are also treated. As not all rats respond equally to the induction of diabetes or insulin treatment, much care has to be taken so as not to induce hypoglycaemia in these animals, which can result in death. To make this information more clear the sentence "To maintain glucose levels in the most normal physiological levels and in order to avoid hypoglycaemia a slow acting insulin with a maintained effect for at least 12 hours was injected" has been included in the material and methods, in the section of control of body weight and glycemia levels.

Also there is no information about the specific dosage in the methods or the figures, which make is very hard to interpret the potency and effectiveness of the treatments.

The insulin dose was adjusted depending on glycemia levels according to the following criteria: no insulin if glycemia was $<50 \mathrm{mg} / \mathrm{dl}, 1 \mathrm{U}$ of insulin if glycemia was between $50-70 \mathrm{mg} / \mathrm{dl}, 2 \mathrm{U}$ of insulin if glycemia was between $70-100 \mathrm{mg} / \mathrm{dll}$, $4 U$ of insulin if glycemia was between $100-200 \mathrm{mg} / \mathrm{dl}, 6 \mathrm{U}$ of insulin if glycemia was between $200-400 \mathrm{mg} / \mathrm{dl}, 7 \mathrm{U}$ of insulin if glycemia was between 400-500 $\mathrm{mg} / \mathrm{dl}$, and $8 \mathrm{U}$ of insulin if glycemia was $>500 \mathrm{mg} / \mathrm{dl}$. This information is given in the material and methods, in the section of control of body weight and glycemia levels. In addition, the administered doses of both insulin and GHRP-6 have been added to each figure legend.

Also relevant to the stated dosage range, insulin normally should be administered proportionally according to body weight. It is not clear that this was the way insulin was administrated. The authors need to clarify 
and expand on that, and to repeat some of the experiments using the same insulin dose in order to verify their results.

Insulin was administered as U/day without taking into account the body weight as the same type of insulin was administered previously to rats following this protocol (Alba-Loureiro et al 2006, Anjos-Valotta et al. 2006, Cerchiaro et al. 2001; In addition, as mentioned above, insulin was administered in attempts to maintain glucose levels in a more normal range, while administration of the same dose of insulin to animals will result in larger fluctuations in glucose levels. These two options, modification of insulin dose or a single insulin dose, address the question with two different endpoints, more normalized glucose or larger variations in glycemia.

References:

Alba-Loureiro TC, Hirabara SM, Mendonça JR, Curi R, Pithon-Curi TC. Diabetes causes marked changes in function and metabolism of rat neutrophils. J Endocrinol. 2006 Feb;188(2):295-303;

Anjos-Valotta EA, Martins JO, Oliveira MA, Casolari DA, Britto LR, Tostes RC, Fortes ZB, Sannomiya P. Inhibition of tumor necrosis factor-alpha-induced intercellular adhesion molecule-1 expression in diabetic rats: role of insulin. Inflamm Res. 2006 Jan;55(1):16-22;

Cerchiaro GA, Scavone C, Texeira S, Sannomiya P. Inducible nitric oxide synthase in rat neutrophils: role of insulin. Biochem Pharmacol. 2001 Aug 1;62(3):357-62).

Also, it is the "norm" in this type of experiments to do a titration study first, and then focus in on a specific dose.

The tritation studies are a very good suggestion and this will indeed be taken into consideration in future studies to determine the effects of different insulin doses on specific outcomes.

3. This work bears a significant resemblance to the authors' previous publication: Mol Cell Endocrinology 309:67-75 (ref 17) on Ghrelin's protective effect against apoptosis in diabetic rats. The authors should make more direct comparisons to their prior research in order to make clear what new discovery this paper contributes to the current state of knowledge. 
In our previous publication we showed that ghrelin treatment for 2 weeks decreased diabetes-induced apoptosis in the pituitary. The treatment consisted of a continuous infusion of ghrelin through the jugular vein from the sixth to the eighth week after diabetes onset, when the illness was completely established. In the current study we administered GHRP-6, a synthetic GH secretagogue that binds to the same receptor than ghrelin, the GHS-R. However in this case the treatments were initiated the following day from diabetes onset and prolonged until sacrifice at the eighth week. Thus, one of our aims was to analyze if GHRP-6 was able to prevent the development of some of the diabetes-induced alterations in the pituitary, hypothalamus and cerebellum. To make the differences more clear between the duration of ghrelin and GHRP-6 administration in this study and in the previous one the sentence "ghrelin treatment of diabetic rats from the sixth to the eighth week from diabetes onset" has been added to the discussion section.

In addition there is evidence suggesting that ghrelin could also act through other receptors other than GHS-R (Baldanzi et al., 2002; Filigheddu et al., 2007; Granata et al., 2007; Granata et al., 2006). As GHRP-6 is a GHS-R-1a agonist our second aim was to analyze if ghrelin's protective effects were mediated by the GHS-R-1a receptor. Since GHRP-6 administration does not have any effect preventing cell death in any of the tissues studied we state in the discussion section that ghrelin protective effects are most likely mediated by other receptor different than GHS-R-1a.

Furthermore it is plausible that the different routes of administration of ghrelin (i.v.) and GHRP-6 (s.c.) could also have an impact in the different effects found. Indeed as ghrelin was continuously infused it was possible to maintain elevated concentrations of this hormone in the serum. On the contrary GHRP-6 was administered subcutaneously once a day. In addition GHRP-6 is reported to have a short half life (Bowers et al 1992), so it is understandable that its effects are more reduced. This explanation has also been included in the discussion section with the sentence. "The fact that the plasma concentrations of ghrelin were maintained elevated over the two week period of treatment in the previous study and that GHRP-6, which has a short half life, was only injected once daily in this study could also be a cause for the different effects found".

References: 
Bowers CY, Alster DK, Frentz JM. The growth hormone-releasing activity of a synthetic hexapeptide in normal men and short statured children after oral administration. J Clin Endocrinol Metab. 1992 Feb;74(2):292-8.

\section{Minor concerns:}

1. There appear to be discrepancies in the quantification of Western Blots. In some of the figures, when looking at the blots, it is hard to imagine the error bars could be that small. Authors stated that 4-6 samples were used, and in the paper they showed only 2 samples. Maybe the authors should choose more representative blots?

The blots of XIAP in the pituitary (Figure $2 \mathrm{C}$ ) and caspase-3 in the cerebellum (Figure $8 \mathrm{C}$ ) have been changed for more representative ones.

\section{Fig 5. has two "A"s.}

This has been corrected.

Reviewer \#2: Granado et al investigated the respective effects of insulin and of GHRP6 on the pituitary, hypothalamus and cerebellum of rats made diabetic through one injection of streptozotocin.

The most important findings are in my mind the fact that hypothalamic cell death and cerebellum PCNA were only normalized by administration of both insulin and GHRP-6 (but not by insulin alone).

This paper builds on and complements recently published data (Ref 42). The article is well-written and easy to follow.

\section{Major comments}

1. Methods: GHRP-6 was injected at the dose of $150 \mathrm{microg} / \mathrm{kg} / \mathrm{day}$. Please justify the dose.

The dose was chosen according to previous published articles in which similar dosages of $\mathrm{GH}$ secretagogues were administered. This is now referenced in the manuscript, in the material and methods section with the sentence "The dose of GHRP-6 was selected from previous studies [32,42-44]." 
2. Results: a short summary of the glucose and weight data (reported in the Endocrinology paper in May 2010) would be important. It would make clear that the dose of insulin used led to a near-normalization of the weight and that blood glucoses, although much improved, remained 2-3 times higher than in non diabetic animals. I realize that this is mentioned in the discussion but a few sentences at the begining of the "results" section would help.

As suggested, a summary of the glucose and body weight data has been included at the beginning of the results section.

3. Results: each group included 11-12 animals but the figures only report results for 4-6 animals. Was this due to death of animals, multiple use of small tissues, other? If so, could the individual results (glucose in particular) explain some of the findings? For instance, within each group of 4-6 samples, there might be large variations of blood glucose that may affect the consistency of the results.

Fortunately only two animals out of 60 died during the experiment, one of them belonging to DB+SALINE group and the other one to DB+GHRP-6 group. The reason for having analyzed only 4-6 samples out of 11-12 was the size of the tissues, especially in the case of pituitaries and hypothalamus. As they are very small tissues it is necessary to lyse the entire pituitary/hypothalamus to obtain a decent amount of protein for the Western Blot or RNA for the PCR assays. For that reason 4-6 samples were randomly selected to perform the Western Blot assays and other 4-6 samples for the PCR assays. The mean glycemia levels of the animals chosen for each technique are shown below:

Animals selected for Western Blot:

\begin{tabular}{|c|c|c|c|c|}
\hline CONTROLS & DB+SALINE & DB+GHRP-6 & DB+INS & DB+INS+GHRP-6 \\
\hline $83 \pm 2$ & $508 \pm 21$ & $514 \pm 10$ & $181 \pm 12$ & $216 \pm 19$ \\
\hline
\end{tabular}

Animals selected for Real Time PCR:

\begin{tabular}{|c|c|c|c|c|}
\hline CONTROLS & DB+SALINE & DB+GHRP-6 & DB+INS & DB+INS+GHRP-6 \\
\hline $78 \pm 2$ & $526 \pm 15$ & $543 \pm 7$ & $188 \pm 9$ & $193 \pm 18$ \\
\hline
\end{tabular}


The glycemia levels between animals of the same group were not different, and the standard error deviation (SEM) of each individual group was relatively small (not exceeding $10 \%$ in any group) even when subdivided between the two assay procedures.

Minor comments

a. Introduction, second page, L1: controlled diabetes This has been corrected.

b. Fig 5, bottom. Should be labeled as $C$, not $A$

This has been corrected.

c. Last line of "results" section. Reference should be a number This has been corrected.

Reviewer \#3: The authors analyzed the effect of insulin and GHRP-6 on diabetes-induced apoptosis in the pituitary, hypothalamus and cerebellum of diabetic rats. Their data show that diabetic rats experienced increased cell death in the pituitary, hypothalamus and cerebellum. In the pituitary, insulin treatment prevented diabetes-induced apoptosis and the decline in prolactin and GH mRNA. In the hypothalamus, neither insulin nor GHRP-6 decreased diabetes-induced cell death. Treatment with both insulin and GHRP-6 prevented the diabetes induced-decrease in GFAP levels. In the cerebellum, insulin treatment increased GFAP levels and treatment with both agents decreased diabetes-induced apoptosis.

These studies follow a previous report from this group that found insulin treatment of diabetic rats prevented hyperphagia, polydipsia and weight loss and reduced hyperglycemia. They also reported that although GHRP6 administration did not attenuate hyperglycemia or weight loss, there was an additive effect of the two hormones on body weight.

The manuscript is well written, the data well presented and organized and the discussion thoughtful. The data is novel and presents insight into the changes in the CNS accompanying diabetes and the effects of therapeutic 
interventions. Although the knowledge gained is incremental, the data is important as we attempt to further understand CNS alterations in diabetes.

\section{The authors are asked to justify the use of PCNA, a proliferative marker} in tissues such the pituitary and hypothalamus that do not have significant cellular proliferation.

Indeed, as the referee states, under normal physiological conditions cell proliferation is very low in the pituitary and hypothalamus, although easily detectable by the method used here. However, when faced with an increase in cell death due to trauma or other insults such as diabetes, cell proliferation is often modified in response. Moreover, GHRP-6 and ghrelin have been shown to stimulate cell proliferation in some cell types. Thus, we initially hypothesized that cell proliferation may be one response that is altered by diabetes and may be stimulated by the treatments used here in order to maintain the cell population in the face of increased cell death. To easily understand the measurement of cell proliferation the sentence "and decrease cell proliferation" has been included in the introduction section.

\section{The authors' understanding of the increase in $\mathrm{LH}$ and FSH in the} diabetic rats.

The increase in $\mathrm{FH}$ and LH pituitary content had already been reported by other authors and seems to be due, at least in part, to increased number of gonadotrophes in the pituitary of diabetic rats (Rossi et al 1981, Bestetti et al 1985, Pitton et al 1987, Bestetti et al 1989). However, as previously described, the serum levels of both $\mathrm{LH}$ and FSH are decreased in response to diabetes. The fact that the LH and FSH pituitary content are increased but the serum levels of these hormones are decreased most likely indicates an inhibition of $\mathrm{LH}$ and FSH secretion from pituitary cells, as previously reported (Palomino et al 1998). Indeed it has been reported that the diabetes-induced decrease of serum LH is due to a decreased pulsatility of this hormone (Dong et al 1991). In addition in diabetic rats are decreased both the regulated and the constitutive LH pituitary secretion (Bestetti et al 1992). The decreased secretion of LH and $\mathrm{FSH}$ is reported to be due to a reduced number of LHRH receptor sites in the 
pituitary gland (Bestetti et al 1997). In addition as TNF-a is increased in the pituitary of STZ-diabetic rats (Arroba et al 2006), and different cytotokines have been reported to strongly inhibit LH and FSH secretion from pituitary cells (Reviewed by Tomaszewska-Zaremba and Herman, 2009) the impaired secretion of these two hormones could be do to increased levels of cytotokines. To clarify this aspect the sentences "On the contrary $\mathrm{LH}$ and FSH pituitary content are increased in responde to diabetes. This effect has already been reported by other authors and seems to be do to increased number of gonadothropes [1,52-54] and decreased LH and FSH secretion [55-56]" and "Furthermore, insulin decreased the diabetes-induced rise in pituitary FSH and LH mRNA levels" have been included in the discussion section of the manuscript.

References:

Bestetti G, Locatelli V, Tirone F, Rossi GL, Müller EE. One month of streptozotocin-diabetes induces different neuroendocrine and morphological alterations in the hypothalamo-pituitary axis of male and female rats.

Bestetti GE, Boujon CE, Reymond MJ, Rossi GL. Functional and morphological changes in mediobasal hypothalamus of streptozocin-induced diabetic rats. In vitro study of LHRH release. Diabetes. 1989 Apr;38(4):471-6.

Bestetti GE, Barone D, Walz A, Moser B, Boujon CE, Brändli-Baiocco A, Rossi GL. $\mathrm{LHRH}$ receptors and $\mathrm{LHRH}$ receptor-bearing cells in pituitaries of streptozocin diabetic male rats. Pharmacol Res. 1997 Apr;35(4):321-7.

Dong Q, Lazarus RM, Wong LS, Vellios M, Handelsman DJ. Pulsatile LH secretion in streptozotocin-induced diabetes in the rat. J Endocrinol. 1991 Oct;131(1):49-55.

Palomino Garibay MA, Revilla Monsalve C, Cárdenas Sánchez A, Polanco Ponce AC, Islas Andrade S. Effect of induced diabetes on reproduction and development. Ginecol Obstet Mex. 1998 Oct;66:403-6. Spanish.

Pitton I, Bestetti GE, Rossi GL. The changes in the hypothalamo-pituitarygonadal axis of streptozotocin-treated male rats depend from age at diabetes onset. Andrologia. 1987 Jul-Aug;19(4):464-73.

Rossi GL, Bestetti G. Morphological changes in the hypothalamic-hypophysealgonadal axis of male rats after twelve months of streptozotocin-induced diabetes. Diabetologia. 1981 Nov;21(5):476-81. 
Tomaszewska-Zaremba D, Herman A. The role of immunological system in the regulation of gonadoliberin and gonadotropin secretion. Reprod Biol. 2009 Mar;9(1):11-23. Review.

\section{A decrease in mRNA and protein could be due to a decrease in} expression or synthesis as well as death of specific cell types. The authors are asked to further discuss how their data may help differentiate these mechanisms.

This is a very good observation and question. In the studies reported here we cannot differentiate these two options as the number of each cell type was not analyzed. Although we have previously shown that diabetes can modify the number of specific cell types, such as lactotrophs in the pituitary or astrocytes in the hypothalamus and cerebellum, the effects of treatments could be through changes in the number of cells or the synthesis of a specific hormone/protein. Indeed, our present results show that the decreased PRL pituitary content is not only due to increased apoptosis of lactotrophs but also to a decreased synthesis of this hormone by the existing prolactin producing cells, as it is revealed by the decrease in PRL mRNA levels. To clarify this effect the sentence "In addition, the decreased gene expression of PRL in saline treated STZ-diabetic rats indicates that the decrease in PRL pituitary content is not only due to decreased number of lactotrophs but also to decrease synthesis of this hormone by the existing prolactin producing cells" has been included in the discussion section.

Likewise, we had previously reported that the decreased GFAP levels in the hypothalamus and the cerebellum of STZ-diabetic rats could be due, at least in part, to increased cell death of astrocytes. However it is true that GFAP content not only depends on the number of astrocytes but can also vary in response to different stimuli. These stimuli could modify the morphology of the astrocytes, for example, prolonging or shortening its projections, and this would be translated in an increased or a decrease in GFAP levels. As we have not measured GFAP mRNA levels either in the hypothalamus or in the cerebellum we cannot exclude that apart from decreased number of astrocytes the decreased GFAP levels could be the result of decreased synthesis of this protein. This has been included in the discussion section of the manuscript with 
the sentences "most likely indicating increased cell death of astrocytes, However decreased synthesis of GFAP by the existing astrocytes cannot be excluded."

4. The use of actin as a control in tissues experiencing cell death is questioned; especially since some of the Western blots show changes in actin expression. The authors are asked to consider using an additional control.

Actin was used for normalization of pituitary and cerebellum as no significant change was found in these tissues in these experiments or in previous experiments using the same or similar experimental protocols. The slight variations that might appear on the blots could be due to loading variations. On the contrary, actin was modified in the hypothalamus of diabetic rats. For that reason we selected GAPDH, which did not change, as the control protein in the hypothalamus.

5. The treated rat models experience periods of hyperglycemia, making them susceptible to the potential confounding effects of excess glucose. This may complicate results and data interpretation. The authors are asked to comment.

It is true that the changes in glucose levels, and not only hyperglycemia but also hypoglycaemia, could affect the results. The referee is correct that this is a limitation of the experiment and that it complicates the data interpretation. To make more clear this statement the sentence "For this reason we cannot exclude that the lack of effects of insulin in the cerebellum and hypothalamus could be due, at least in part, to the still increased glucose levels or the daily variations in glycemia." has been included in the discussion section. However, although still increased in comparison to control animals, glycemia was maintained significantly lower in insulin-treated rats than in saline injected rats throughout the experiment. Thus, although there were variations in glycemia levels, insulin treated rats were more controlled than non treated animals. 


\title{
Insulin and growth hormone-releasing peptide-6 (GHRP-6) have
}

\author{
differential beneficial effects on cell turnover in the pituitary,
}

hypothalamus and cerebellum of streptozotocin (STZ)-induced

\section{diabetic rats}

Miriam Granado ${ }^{1,2}$, Cristina García-Cáceres ${ }^{1}$, María Tuda ${ }^{1}$, Laura M. Frago

${ }^{1}$, Julie A. Chowen ${ }^{1}$, Jesús Argente ${ }^{1}$

${ }^{1}$ Department of Endocrinology, Hospital Infantil Universitario Niño Jesús,

Department of Pediatrics, Universidad Autónoma de Madrid, Instituto de Investigación

Sanitaria La Princesa and CIBER Fisiopatología de Obesidad y Nutrición, Instituto de

Salud Carlos III, Madrid, Spain.

${ }^{2}$ Department of Physiology. Facultad de Medicina. Universidad Autónoma de Madrid.

\section{Corresponding author:}

Jesús Argente, M.D., Ph.D.

Professor \& Chairman

Department of Pediatrics \& Pediatric Endocrinology

Hospital Infantil Universitario Niño Jesús

Avenida Menéndez Pelayo, 65

28009 Madrid, Spain

E-mail: argentefen@terra.es, jesus.argente@uam.es

Telephone/FAX: 34-91-5035939

This work was funded by grants from Fondos de Investigación Sanitaria (PI070182), Ministerio de Ciencia e Innovación (BFU2008-02950C03-3), CIBER Fisiopatología de Obesidad y Nutrición (CIBEROBN) Instituto de Salud Carlos III and Fundación de Endocrinología y Nutrición. MG is supported by the Juan de la Cierva program, CG-C a predoctoral fellowship from the Ministerio de Educación y Ciencia (FPU 
AP2006/02761) and JAC by the biomedical investigation program of the Consejería de Sanidad y Consumo de la Comunidad de Madrid.

\section{ABSTRACT}

Poorly controlled type 1 diabetes is associated with hormonal imbalances and increased cell death in different tissues, including the pituitary, hypothalamus and cerebellum. In the pituitary, lactotrophs are the cell population with the greatest increase in cell death, whereas in the hypothalamus and cerebellum astrocytes are most highly affected. Insulin treatment can delay, but does not prevent, diabetic complications. As ghrelin and growth hormone $(\mathrm{GH})$ secretagogues are reported to prevent apoptosis in different tissues, and to modulate glucose homeostasis, a combined hormonal treatment may be beneficial. Hence, we analyzed the effect of insulin and GH-releasing peptide 6 (GHRP-6) on diabetesinduced apoptosis in the pituitary, hypothalamus and cerebellum of diabetic rats. Adult male Wistar rats were made diabetic by streptozotocin injection $(65 \mathrm{mg} / \mathrm{kg} i p)$ and divided into four groups from diabetes onset: those receiving a daily $s c$ injection of saline (1 ml/kg/day), GHRP-6 (150 $\mu \mathrm{g} / \mathrm{kg} /$ day), insulin (1-8 U/day) or insulin plus GHRP-6 for 8 weeks. Control non-diabetic rats received saline $(1 \mathrm{ml} / \mathrm{kg} /$ day $)$. Diabetes increased cell death in the pituitary, hypothalamus and cerebellum $(\mathrm{P}<0.05)$. In the pituitary, insulin treatment prevented diabetes-induced apoptosis $(\mathrm{P}<0.01)$, as well as the decline in prolactin and GH mRNA levels $(\mathrm{P}<0.05)$. In the hypothalamus, neither insulin nor GHRP-6 decreased diabetes-induced cell death. However, the combined treatment of insulin+GHRP6 prevented the diabetes induced-decrease in glial fibrillary acidic protein (GFAP) levels $(\mathrm{P}<0.05)$. In the cerebellum, although insulin treatment increased GFAP levels $(\mathrm{P}<0.01)$, only the combined treatment of insulin+GHRP-6 decreased diabetes-induced apoptosis $(\mathrm{P}<0.05)$. In conclusion, insulin and GHRP-6 exert tissue specific effects in STZ-diabetic rats and act synergistically on some processes. Indeed, insulin treatment does not seem to 
be effective on preventing some of the diabetes-induced alterations in the central nervous system.

Key words: Diabetes, apoptosis, insulin, GHRP-6, ghrelin, pituitary, hypothalamus, cerebellum.

\section{INTRODUCTION}

Diabetes mellitus, the most common chronic disease in childhood, results in long-term complications when poorly controlled over an extended period of time. Indeed, poor glycemic control is not only associated with metabolic and hormonal imbalances [1-3], but also with an increased risk of disorders in the central nervous system (CNS) as a result of changes in brain metabolism, vascular reactivity, blood-brain barrier integrity and increased oxidative stress [4-6]. Some of these alterations could be due, at least in part, to increased apoptosis of both neurons and glia cells, as chronic hyperglycemia has been reported to induce cell death of cortical, hippocampal and hypothalamic neurons [7-9], as well as to induce cell death and decrease cell proliferation of astrocytes both in vivo and in vitro [10-14].

Alterations in the cellular composition of the anterior pituitary could also be involved in some of the diabetes-induced endocrine disruptions, as this gland undergoes increased apoptosis in poorly controlled STZ-diabetic rats [15-17]. Moreover, the increased cell death is cell-type specific, with lactotrophs being most highly affected [16] as a result of caspase-8 activation $[15,17]$. However, pituitary levels of proteins involved in the intrinsic cell death pathway, including members of the Bcl-2 family, the effector caspase 3 and the anti-apoptotic proteins Hsp-70 and XIAP, are either unchanged or balanced towards cell survival $[15,17]$.

Astrocytes play a major role in the homeostatic regulation of the CNS as they are involved in neurotransmitter uptake, neuronal metabolic support, $\mathrm{pH}$ regulation, and neuralprotection against toxic episodes such as excitotoxicity and oxidative stress [18-20]. In poorly 
controlled diabetes a decrease in GFAP levels has been reported both in the cerebellum and hypothalamus as a result of increased death of astrocytes [11-13]. However the mechanism by which these glial cells undergo apoptosis is different in these two brain areas. In the hypothalamus this process involves nuclear translocation of apoptosis inducing factor (AIF) [11], whereas in the cerebellum activation of the intrinsic cell death pathway occurs [13].

Many of the diabetes-induced endocrine and CNS disruptions are prevented after insulin replacement, which is due largely to the improvement in glycaemia and metabolism [2122]. However, insulin also has direct effects on cell survival. Indeed, insulin decreases neuronal death both in vivo and in vitro [9,23-26].

GHRP-6 is a synthetic compound that binds to the ghrelin receptor (GHS-R) and promotes GH secretion [27-28]. In addition, both ghrelin and GH secretagogues (GHSs) exert GH-independent effects such as stimulation of food intake [29], induction of adiposity [30], antiinflammatory effects [31-32] and anti-apoptotic actions [33-35]. Indeed, GHRP-6 protects hypothalamic neurons from glutamate excitotoxicity [36], decreases age-induced cell death in the cerebellum [37] and activates intracellular signaling pathways involved in neuroprotection [38]. Furthermore ghrelin, the endogenous ligand of GHS-R, prevents diabetes-induced apoptosis of lactotrophs [17] and the development of diabetes during adulthood in rats treated neonatally with streptozotocin [39]. Ghrelin is also involved in the regulation of insulin secretion and glucose metabolism [40] and the combined treatment of diabetic rats with insulin and GHRP-6 has additive effects on body composition [41] .

Thus, the aim of this study was to analyze the possible protective effect of GHRP-6 both in the presence and absence of insulin treatment in the development of diabetes induced alterations of the anterior pituitary, the hypothalamus and the cerebellum. 


\section{MATERIAL AND METHODS}

\section{Animals}

All experiments were designed according to the European Union laws for animal care and the study was approved by the local institutional ethical committee. Adult male Wistar rats from Harlan Iberica S.A. (Barcelona, Spain) were housed two per cage with free access to food and water, under constant conditions of temperature $\left(20-22^{\circ} \mathrm{C}\right)$ and light/dark cycles (lights on from 07:30 to 19:30). Before diabetes induction, rats were adapted for one week to the new environment and diet.

The rats, weighing approximately $250 \mathrm{~g}$, were injected (i.p.) with $65 \mathrm{mg} / \mathrm{kg}$ streptozotocin (Sigma, Steinheim, Germany). Controls received vehicle. Blood glucose concentrations were measured via tail puncture (Glucocard Memory 2; Menarini Diagnostic, Florence, Italy) to verify the diabetic state (defined as blood glucose levels $>300 \mathrm{mg} / \mathrm{dl}$ ). Immediately after the onset of diabetes, the rats were randomly divided into treatment groups.

The treatments consisted in a daily subcutaneous $(s c)$ injection of saline $(1 \mathrm{ml} / \mathrm{kg}, \mathrm{n}=11)$, GHRP-6 (Bachem, Bubendorf, Swizerland, $150 \mu \mathrm{g} / \mathrm{kg} / \mathrm{day}, \mathrm{n}=11$ ), insulin (Humulin NPH Pen $100 \mathrm{IU} / \mathrm{ml}, 1-8 \mathrm{U} / \mathrm{day}, \mathrm{n}=12)$ or insulin plus GHRP-6 $(\mathrm{n}=12)$. The dose of GHRP-6 was selected from previous studies [32,42-44]. Control rats received saline $(\mathrm{n}=12)$. All rats received their treatments between 18.00 and 19.00 just before the lights were turned-off and the animals naturally began their feeding period. After 8 weeks of treatment, all rats were killed by decapitation 15 hours after the last injection. Trunk blood was collected in cooled tubes, allowed to clot, and then centrifuged. Serum was stored at $-80^{\circ} \mathrm{C}$ until hormone levels were measured. The brains and pituitaries were removed, weighed and stored at $-80^{\circ} \mathrm{C}$ until processed.

\section{Control of body weight and glycemia levels}

Glycemia and body weight were assessed daily before treatment administration. To maintain glucose levels in the most normal physiological levels and in order to avoid 
hypoglycaemia a slow acting insulin with a maintained effect for at least 12 hours was injected and the insulin dose was adjusted depending on glycemia levels according to the following criteria: no insulin if glycemia was $<50 \mathrm{mg} / \mathrm{dl}$, $1 \mathrm{U}$ of insulin if glycemia was between $50-70$ $\mathrm{mg} / \mathrm{dl}, 2 \mathrm{U}$ of insulin if glycemia was between $70-100 \mathrm{mg} / \mathrm{dl}, 4 \mathrm{U}$ of insulin if glycemia was between 100-200 mg/dl, $6 \mathrm{U}$ of insulin if glycemia was between $200-400 \mathrm{mg} / \mathrm{dl}, 7 \mathrm{U}$ of insulin if glycemia was between $400-500 \mathrm{mg} / \mathrm{dl}$, and $8 \mathrm{U}$ of insulin if glycemia was $>500 \mathrm{mg} / \mathrm{dl}$.

\section{$\underline{\text { Tissue homogenization and protein quantification }}$}

Tissue was homogenized on ice in $200 \mu$ l of radioimmunoprecipitation assay lysis buffer with an EDTA-free protease inhibitor cocktail (Roche Diagnostics, Mannheim, Germany). After homogenization, samples were centrifuged at 14,000 rpm for $20 \mathrm{~min}$ at $4 \circ \mathrm{C}$. Supernatants were transferred to a new tube and protein concentration was estimated by Bradford protein assay.

\section{$\underline{\text { ELISA cell death detection }}$}

This photometric enzyme immunoassay for the quantification of cytoplasmic histoneassociated DNA fragments (mono- and oligonucleosomes) was performed according to the instructions of the manufacturer (Roche Diagnostics). The same amount of total protein was loaded in all wells and each sample was measured in duplicate (Tecan InfiniteM200, Grödig, Austria). The background value was subtracted from the mean value of each sample and all values are referred to the mean value of the control group.

\section{Immunoblotting}

In each assay the same amount of protein was loaded in all wells $(1-60 \mu \mathrm{g})$ depending on the protein to be detected and resolved by using $12 \%$ SDS-acrylamide gels. After electrophoresis proteins were transferred to polyvinylidine difluoride (PVDF) membranes (Bio-Rad) and transfer efficiency was determined by Ponceau red dyeing. Filters were then blocked with Tris-buffered saline (TBS) containing 5\% (w/v) non-fat dried milk and incubated with the appropriate primary 
antibody (for details, see Table 1). Membranes were subsequently washed and incubated with the corresponding secondary antibody conjugated with peroxidase (1:2000; Pierce, Rockford, IL, USA). Bound peroxidase activity was visualized by chemiluminescence and quantified by densitometry using a Kodak Gel Logic 1500 Image Analysis System and Molecular Imaging Software, version 4.0 (Rochester, NY, USA). All blots were rehybridized with actin or glyceraldehyde 3-phosphate dehydrogenase (GAPDH) to normalize each sample for gel-loading variability. All data are normalized to control values on each gel.

\section{$\underline{R N A}$ preparation and purification and quantitative real-time PCR}

Total RNA was extracted from the pituitaries, hypothalami and cerebelli according to the Tri-Reagent protocol (Chomczynski et al 1993). cDNA was then synthesized from $1 \mu \mathrm{g}$ of total RNA using a high capacity cDNA reverse transcription kit (Applied Biosystems, Foster City, CA, USA).

\section{Quantitative real-time PCR}

Growth hormone (GH), prolactin (PRL), pro-opiomelanocortin (POMC), thyroidstimulating hormone (TSH), luteinizing hormone ( $\mathrm{LH})$, follicle-stimulating hormone (FSH) and tumour necrosis factor $\alpha(\mathrm{TNF}-\alpha)$ mRNAs were assessed in pituitary samples by quantitative real-time PCR. Insulin-like growth factor I (IGF-I), IGF-I receptor (rIGF-I), GHS receptor (GHS$\mathrm{R}$ ), and insulin receptor (INS-R) mRNAs were measured in the pituitaries, hypothalami and cerebelli. Quantitative real-time PCR was performed by using assay-on-demand kits (Applied Biosystems) for each gene: FSH (Rn01484594), GH (Rn01495894), GHS-R (Rn00821417), IGF-I (Rn99999087), rIGF-I (Rn01477918), INS-R (Rn00567670), LH (Rn00563443), POMC (Rn00595020), PRL (Rn00440945), TNF- $\alpha$ (Rn01525859), TSH (Rn00565424). TaqMan Universal PCR Master Mix (Applied Biosystems) was used for amplification according to the manufacturer's protocol in an ABI PRISM 7000 Sequence Detection System (Applied Biosystems). Values were normalized to the housekeeping gene 18S (Rn01428915). According 
to manufacturer's guidelines, the $\Delta \Delta \mathrm{CT}$ method was used to determine relative expression levels. Statistics were performed using $\Delta \Delta \mathrm{CT}$ values [45].

\section{Statistical analysis}

Statistics were performed using the statistics program GraphPad Prism 4.0. Two-way analysis of variance (ANOVA) was used to determine the effect and interaction of treatments on the measured outcomes in diabetic rats. Differences among experimental groups were analyzed by one-way ANOVA and post hoc comparisons were made using subsequent Bonferroni multiple range tests. Data are presented as mean \pm SEM and the values were considered significantly different when the $\mathrm{P}$ value was lower than 0.05 .

\section{RESULTS}

\section{Glycemia and body weight gain}

We have previously reported that the diabetic rats injected with saline or GHRP6 had decreased bodyweight gain and increased glycaemia compared to control animals [41]. Insulin treatment resulted in bodyweight gain similar to that observed in control rats and significantly decreased glycaemia compared to saline-injected rats, although their glycaemia levels were still significantly increased compared to non-diabetic animals. Diabetic rats treated with insulin and GHRP-6 gained more weight than rats from all other experimental groups, including control animals. However, their glycaemia levels, although significantly reduced compared to saline-treated diabetic rats were still higher than those of control rats [41].

\section{Pituitary}

\section{Cell death, total protein content and proliferating cell nuclear antigen (PCNA) levels}


Diabetes increased cell death (Fig $1 \mathrm{~A} ; \mathrm{P}<0.05)$ and decreased total protein content (Fig 1B; $\mathrm{P}<0.001$ ) and proliferating cell nuclear antigen (PCNA) levels (Fig 1C; $\mathrm{P}<0.001$ ) in the pituitary. Insulin, but not GHRP-6, normalized the diabetes-induced increase in cell death and total protein content and the decrease in pituitary PCNA levels, with no interaction between the two factors.

\section{Pituitary hormone mRNA levels}

The mRNA levels of GH, PRL, POMC, TSH, LH and FSH in the pituitary of control and diabetic rats are shown in Table 2. GH mRNA levels were decreased in the pituitary of salineinjected diabetic rats $(\mathrm{P}<0.01)$ and both insulin and GHRP-6 increased the pituitary mRNA levels of this hormone $(\mathrm{P}<0.001$ and $\mathrm{P}<0.05$, respectively), with no interaction between the two factors. Likewise, diabetes decreased the expression of PRL $(\mathrm{P}<0.01)$ and insulin, but not GHRP-6, prevented the diabetes-induced decrease of PRL mRNA levels $(\mathrm{P}<0.01)$, with no interaction between insulin and GHRP-6. On the contrary, pituitary LH and FSH mRNA content were increased in diabetic rats treated with saline $(\mathrm{P}<0.001$ and $\mathrm{P}<0.05$, respectively). Insulin, but not GHRP-6, decreased the diabetes-induced rise in pituitary LH mRNA to control levels, with no interaction between the two factors. However, both insulin and GHRP-6 treated rats returned pituitary FSH mRNA levels to that of control rats $(\mathrm{P}<0.05)$, with an interaction between the two factors $(\mathrm{F}=11.68 ; \mathrm{P}<0.01)$. Pituitary TSH mRNA levels were unchanged in response to diabetes as well as the treatments employed. Likewise, diabetes did not modify POMC levels in the pituitary. However, diabetic rats treated with GHRP-6 had decreased POMC pituitary content compared to controls $(\mathrm{P}<0.001)$ whereas the pituitary levels of this hormone were significantly increased in diabetic rats treated with insulin plus GHRP-6 $(\mathrm{P}<0.001)$.

\section{Pituitary Bcl-2, HSP-70 and XIAP content}

Bcl-2 (Fig.2A; P<0.01), Hsp-70 (Fig. 2B; P<0.05) and XIAP (30kDa, Fig. 2C; P<0.001) were up-regulated in the pituitary of diabetic rats injected with saline $(\mathrm{P}<0.01, \mathrm{P}<0.05$ and 
$\mathrm{P}<0.001$, respectively) and insulin, but not GHRP-6, prevented diabetes-induced up-regulation of these anti-apoptotic proteins, with no interaction between the two treatments.

\section{Caspase-8 and TNF-a in the pituitary}

Caspase- 8 content was increased in the pituitary of diabetic rats injected saline (Figure $3 \mathrm{~A} ; \mathrm{P}<0.01)$ compared to controls. There was no interaction between insulin and GHRP-6, with GHRP-6 having no effect and insulin preventing the diabetes-induced up-regulation of pituitary caspase-8 $(\mathrm{P}<0.001)$.

Likewise, TNF- $\alpha$ gene expression was increased in the pituitary of diabetic rats injected saline compared to control rats (Figure $3 \mathrm{~B} ; \mathrm{P}<0.05$ ) and only insulin treatment prevented the diabetes-induced increased of TNF $\alpha$ mRNA levels, with no interaction between insulin and GHRP-6.

\section{Pituitary IGF-I and rIGF-I mRNA levels}

There was no significant effect of diabetes or the treatments on IGF-I (C+saline: $100 \pm 6$; Db+saline: $163 \pm$ 57; Db+GHRP-6: $76 \pm$ 9; Db+Ins: $105 \pm$ 8; Db+Ins+GHRP-6: $112 \pm$ 9) or rIGF-I mRNA levels (C+saline: $100 \pm$ 5; Db+saline: $185 \pm$ 66; Db+GHRP-6: $153 \pm$ 13; Db+Ins: $100 \pm 6$; Db+Ins+GHRP-6: $110 \pm 7$ ) in the pituitary (Figs. 4A and 4B; P>0.05).

\section{Hypothalamus}

\section{Cell death, PCNA and GFAP levels in the hypothalamus}

Diabetes increased cell death (Figure 5A; $\mathrm{P}<0.01$ ) and decreased PCNA levels (Figure 5B; $\mathrm{P}<0.01)$ in the hypothalamus. There was no interaction between insulin and GHRP-6 either on cell death or PCNA levels in the hypothalamus of diabetic rats. Hypothalamic PCNA content was decreased in all diabetic animals compared to controls, regardless of the treatment received $(\mathrm{P}<0.01$ respectively). In contrast, cell death was increased in the hypothalamus of all diabetic 
animals $(\mathrm{P}<0.05)$, except for those who received the combined treatment in which hypothalamic total cell death was not different from that of control rats.

Hypothalamic GFAP levels were decreased in diabetic rats injected saline (Figure 5C; $\mathrm{P}<0.05)$. Treatment with insulin or GHRP-6 partially normalized GFAP levels such that there was no statistical difference from either control rats or diabetics treated with saline, without an interaction between the two factors. On the contrary, the combined treatment of insulin plus GHRP-6 returned hypothalamic GFAP levels to control levels $(\mathrm{P}<0.05)$.

\section{Hypothalamic IGF-I and rIGF-I mRNA levels}

All diabetic rats, regardless of the treatment, had decreased IGF-I mRNA levels in the hypothalamus compared to controls (Fig. 6A; P<0.001). Neither insulin nor GHRP-6 prevented this decrease, with no interaction between the two factors. On the contrary, although diabetes did not modify the hypothalamic gene expression of rIGF-I, both insulin and GHRP-6 treatments decreased rIGF-I mRNA levels in diabetic rats (Fig. 6B; P<0.01), with no interaction between the two factors.

\section{Cerebellum}

\section{Cell death, PCNA and GFAP levels in the cerebellum}

Diabetes increased cell death in the cerebellum and insulin, but not GHRP-6, prevented this effect with no interaction between the two treatments (Figure 7A; $\mathrm{P}<0.05$ ).

Cell proliferation, as indicated by PCNA content, was decreased in the cerebellum in response to diabetes (Figure 7B; $\mathrm{P}<0.001$ ). There was an interaction between insulin and GHRP$6(\mathrm{~F}=46.52 ; \mathrm{P}<0.001)$ as both insulin and GHRP-6 when administered alone increased PCNA content in the cerebellum compared to controls and to diabetic rats injected with saline $(\mathrm{P}<0.001)$, but when administered together the treatments had no effect. 
GFAP levels in the cerebellum were also decreased in diabetic rats injected saline (Figure 7C; $\mathrm{P}<0.001)$ compared to control rats. Insulin increased GFAP levels $(\mathrm{P}<0.05)$ and GHRP-6 had no effect, with no interaction between treatments. However, only diabetic rats treated with insulin plus GHRP-6 had significantly higher levels of GFAP in the cerebellum than salinetreated diabetic rats

Active caspase-9, caspase-6 and caspase-3 levels in the cerebellum

Activation of both caspase- 9 and caspase- 6 was up-regulated in the cerebellum of diabetic rats treated with saline (Figures $8 \mathrm{~A}$ and $8 \mathrm{~B} ; \mathrm{P}<0.05$ and $\mathrm{P}<0.001$, respectively), while caspase-3 levels were unchanged (Figure 8C). Insulin treatment partially reduced the activation of caspases $9(\mathrm{P}<0.05)$ and $6(\mathrm{P}<0.0001)$ such that they were no longer different from control levels, but also not significantly different from saline treated diabetic rats. GHRP-6 exerted no effect. However, insulin plus GHRP-6 treated rats had significantly lower levels of both caspases compared to saline-injected diabetic rats $(\mathrm{P}<0.05$ and $\mathrm{P}<0.0001$, respectively).

$\underline{I G F-I \text { and rIGF-I mRNA levels in the cerebellum }}$

IGF-I mRNA levels were decreased in the cerebellum of all diabetic animals compared to controls, regardless of the treatment received (Figure 9A; $\mathrm{P}<0.001$ ). However, diabetic rats treated with GHRP-6 had higher IGF-I levels than those injected saline and those treated with the combined treatment of insulin plus GHRP-6 $(\mathrm{P}<0.05)$, without an interaction between insulin and GHRP-6. On the contrary, rIGF-I gene expression was unchanged in response to diabetes (Figure 9B). There was a significant interaction between insulin and GHRP-6 $(\mathrm{F}=38.66, \mathrm{P}<0.0001)$ as GHRP-6 increased rIGF-I gene expression in the cerebellum when it was administered alone $(\mathrm{P}<0.001)$, but not when it was administered with insulin.

\section{$\underline{G H S-R \text { and INS-R mRNA levels in the pituitary, hypothalamus and cerebellum }}$}


As different levels of the GHS-R and INS-R in the pituitary, hypothalamus and cerebellum could play a role in the response to the treatments employed, the gene expression of these receptors were measured in the three different tissues.

GHS-R mRNA levels were increased in the pituitary of diabetic rats injected with saline compared to controls (C+saline: $100 \pm 34$; Db+saline: $277 \pm 45 ; \mathrm{P}<0.05)$, whereas they were unchanged in the cerebellum (C+saline: $100 \pm 37$; Db+saline: $57 \pm 8)$ and in the hypothalamus [46]. In the pituitary GHRP-6 treatment decreased GHS-R mRNA to control levels (C+saline: $100 \pm$ 34; Db+GHRP-6: $105 \pm$ 16), whereas insulin and insulin+GHRP-6 treatments decreased GHS-R mRNA below control levels (C+saline: $100 \pm 34$; Db+Ins: $53 \pm 13$; Db+Ins+GHRP-6: $74 \pm 12 ; \mathrm{P}<0.05)$, with an interaction between insulin and GHRP-6 $(\mathrm{F}=11.67$; $\mathrm{P}<0.01)$. In the cerebellum neither insulin nor GHRP-6 modified GHS-R mRNA levels, with no interaction between the two factors (C+saline: $100 \pm 37$; Db+GHRP-6: $168 \pm 36$; Db+Ins: $151 \pm$ 9; Db+Ins+GHRP-6: $107 \pm 70)$.

In the hypothalamus we have previously reported that treatment with insulin or insulin+GHRP-6 reduced the expression of GHS-R compared to control and saline-injected diabetic rats with an interaction between the two treatments (Granado et al 2010).

Diabetic rats injected saline had increased INS-R mRNA levels in the pituitary $(\mathrm{C}+$ saline: $100 \pm 15$; $\mathrm{Db}+$ saline: $193 \pm 33 ; \mathrm{P}<0.05)$, and cerebellum $(\mathrm{C}+$ saline: $100 \pm 9$; Db+saline: $134 \pm 7 ; \mathrm{P}<0.05)$ compared to controls. There was an interaction between insulin and GHRP-6 treatments on INS-R mRNA levels both in the pituitary $(\mathrm{F}=8.65, \mathrm{P}<0.05)$ and cerebellum $(\mathrm{F}=5.45, \mathrm{P}<0.05)$. While in the pituitary both insulin and GHRP-6 decreased the diabetes-induced up-regulation of INS-R mRNA levels (C+saline: $100 \pm 15$; Db+GHRP-6: $110 \pm$ 15; $\mathrm{Db}+$ Ins: $118 \pm 11$; Db+Ins+GHRP-6: $140 \pm 16$ ), none of the treatments prevented the diabetes-induced modifications of INS-R mRNA levels in the cerebellum $(\mathrm{C}+$ saline: $100 \pm 9$; Db+GHRP-6: 177 \pm 7; Db+Ins: $173 \pm 28 ;$ Db+Ins+GHRP-6: 132 \pm 7 ). 
We previously reported that gene expression of this receptor was decreased in the hypothalamus and that none of the treatments employed had a significant effect [46].

\section{DISCUSSION}

Type- 1 diabetes is associated with structural and functional changes in the CNS and in the pituitary that in many instances can be prevented by insulin replacement [21-22]. The results reported here show that insulin and GHRP-6 treatments exert different protective effects in the pituitary, cerebellum and hypothalamus of STZ-induced diabetic rats and that the combined treatment may be beneficial in some instances.

In a previous study we reported the metabolic and hormonal outcomes of these animals in response to insulin and GHRP-6 treatments [46]. We found that one daily injection of insulin for eight weeks from diabetes onset prevented diabetes-induced hyperphagia, polydipsia and body weight loss and reduced diabetes-induced hyperglycemia in STZ-diabetic rats. On the contrary, GHRP-6 administration for the same period did not attenuate either hyperglycemia or body weight loss in these diabetic rats. However, there was an additive effect of these two hormones on distinct variables, including body weight, suggesting that GHRP-6, and possibly ghrelin, may need the presence of insulin in order to exert its metabolic effects.

In addition to its classical metabolic effects GHRP-6, as well as ghrelin, exerts protective effects on specific cell types, including neurons [36,38] and pituitary cells [17]. As poorly controlled diabetes induces cell death in distinct tissues, which is involved in the development of some of the secondary effects, treatment with this hormone could possibly be beneficial in this disease.

Diabetes increased cell death in the pituitary, hypothalamus and cerebellum as previously reported [11-13,17]. However, while in the pituitary insulin treatment prevented diabetes-induced apoptosis, in the cerebellum and hypothalamus it had no significant effect on cell death. 
Although there was no significant effect of GHRP-6 alone on cell death in any of the areas studied, the combination of insulin and GHRP-6 resulted in levels not different from that found in control animals, suggesting that the combined treatment may be more beneficial than insulin alone.

The different effects exerted by insulin and GHRP-6 in these tissues could be due, at least in part, to the different levels of expression and regulation of the INS-R and GHS-R. Indeed, INS-R mRNA levels were decreased in the hypothalamus of STZ-diabetic rats [46-47], but increased in the pituitary and cerebellum, as shown here and previously [48]. Moreover, insulin differentially affected its receptor levels in these tissues, as it prevented the diabetes-induced alterations of INS-R mRNA levels in the pituitary, but not in the hypothalamus or cerebellum. Contrary to our results, Peeyush et al. found that insulin treatment prevented the diabetesinduced up-regulation of INS-R in the cerebellum. However, in their study blood glucose levels were normalized to control levels after two daily injections of insulin whereas in our study glycemia, although significantly decreased compared to saline-injected rats, remained increased compared to controls [46]. For this reason we cannot exclude that the lack of effects of insulin in the cerebellum and hypothalamus could be due, at least in part, to the still increased glucose levels or the daily variations in glycemia.

Diabetes also induced differential changes in the gene expression of GHS-R. While diabetes increased GHS-R mRNA levels in the pituitary as previously reported [49], no change was observed in the hypothalamus or cerebellum. In addition, both insulin and GHRP-6 treatments blunted the up-regulation of GHS-R mRNA in the pituitary and decreased GHS-R mRNA in the hypothalamus, with no significant effects in the cerebellum. Thus, the differential regulation of the INS-R and GHS-R, both in response to diabetes and the treatment protocols, could underlie, at least in part, the different protective effects of insulin and GHRP-6 in these tissues. 
Since the insulin regimen used did not totally normalize serum glucose levels, the differential susceptibility of the pituitary and CNS cells to hyperglycemia-induced cell death should be taken into consideration, as well as the distinct mechanisms involved in cell death in the three different tissues. Indeed, we previously reported that in the pituitary diabetes-induced apoptosis is mediated by activation of the extrinsic cell death pathway, with an up-regulation of TNF- $\alpha$ and caspase- 8 levels [15-17]. This activation results in decreased PRL content due to increased cell death of lactotrophs [16]. In addition, the decreased gene expression of PRL in saline treated STZ-diabetic rats indicates that the decrease in PRL pituitary content is not only due to decreased number of lactotrophs, but may also be due to decrease synthesis of this hormone by the existing prolactin producing cells. On the contrary LH and FSH pituitary content are increased in response to diabetes. This effect has already been reported by other authors and seems to be do to increased number of gonadothropes [1,52-54] and decreased LH and FSH secretion [55-56]. In the current study insulin treatment, but not GHRP-6, decreased cell death and caspase- 8 activation and increased PRL gene expression in the pituitary, suggesting that insulin replacement protects PRL producing cells from diabetes-induced apoptosis, and/or induce PRL synthesis. Indeed, insulin replacement has been reported to restore the diabetes-induced decrease of PRL levels in STZ-diabetic rats [22] and to induce PRL secretion in pituitary cell cultures [50]. In addition, insulin administration prevented the diabetes-induced down-regulation of total protein content and PCNA levels and the increase in TNF $\alpha$ gene expression and Bcl-2, Hsp-70 and XIAP protein content in the pituitary. This effect does not seem to be mediated by changes in the local IGF-I system, as both IGF-I and rIGF-I mRNAs are unchanged in the pituitary of untreated and treated diabetic rats, as previously reported by other authors [51]. Furthermore, insulin decreased the diabetes-induced rise in pituitary FSH and LH mRNA levels However, although GHRP-6 administration increased both GH mRNA and GH content in the pituitary of diabetic rats [46], it did not attenuate the decline in PRL levels [46] or in pituitary 
cell death. These results are in contrast to what we previously observed with ghrelin treatment of diabetic rats from the sixth to eighth week after diabetes onset, where the diabetes-induced pituitary cell death and decrease in PRL pituitary content were reduced [17]. The discrepancies between these two studies might be explained by the different routes of administration used. In the current study GHRP-6 was injected subcutaneously once daily and in the previous report ghrelin was continuously infused through the jugular vein for two-weeks. The fact that the plasma concentrations of ghrelin were maintained elevated over the two week period of treatment in the previous study and that GHRP-6, which has a short half life, was only injected once daily in this study could also be a cause for the different effects found. Moreover, it is also possible that ghrelin's anti-apoptotic effects are not mediated through the GHS-R1a receptor. Indeed it has been reported that ghrelin induces cell proliferation and inhibits apoptosis in different cell types through a GHSR1a independent mechanism [34,57-59].

We have previously described a decrease in GFAP content in the hypothalamus as a result of diabetes-induced changes in astrocyte morphology and a decrease in the number of astrocytes due, at least in part, to increased cell death (Lechuga-Sancho et al 2006, GarcíaCáceres et al 2008). Likewise, in this study cell death was increased and GFAP levels decreased in poorly controlled diabetic rats, most likely indicating increased cell death of astrocytes, However, decreased synthesis of GFAP by the existing astrocytes cannot be excluded. Although both insulin and GHRP-6 attenuated the diabetes-induced decrease of hypothalamic GFAP levels, none of these treatments prevented cell death. On the contrary, the combination of the two treatments attenuated cell death and returned GFAP levels to control values. Thus, insulin and GHRP-6 may also be modulating GFAP levels through a process other than cell protection, including stimulation of proliferation or induction of morphological changes. However, although insulin is important for the maintenance of astrocyte function and induces astrocyte differentiation in vitro [60-64], we found no effect of insulin, or GHRP-6, on hypothalamic 
PCNA levels. Thus, the increased hypothalamic GFAP levels in diabetic rats treated with insulin+GHRP-6 do not appear to be the result of increased proliferation. However, it has recently been proposed that obesity can affect astrocytes, increasing hypothalamic GFAP levels [65-66]. Hence, as diabetic rats administered insulin and GHRP-6 have increased body weight gain, adiposity and serum leptin levels compared to control rats (Granado et al 2010), the increased hypothalamic GFAP levels could be related to the change in body composition.

In the cerebellum cell death was increased and GFAP decreased in response to diabetes, as previously described [13]. However, although our group has reported that the decrease in GFAP is due, at least in part, to a decreased number of astrocytes it has also been reported that the number of astrocytes in the cerebellum is unchanged in response to diabetes [67]. Insulin treatment prevented the diabetes induced decrease in GFAP levels in the cerebellum as previously reported [68], but it only partially decreased cell death and the up-regulation of caspases 9 and 6. In contrast, PCNA content was increased in the cerebellum of insulin-treated diabetic rats compared to saline-injected animals, suggesting that the increased GFAP levels could be the result of increased proliferation of glial cells and/or stimulation of GFAP expression in the existing astrocytes. Indeed, insulin has been reported to increase GFAP expression and cell proliferation in astrocyte primary cultures $[61,64]$. However, GHRP-6 treatment of diabetic rats also increased PCNA levels in the cerebellum without increasing GFAP levels, which could indicate that GHRP-6 induces proliferation of other cell types different than astrocytes, which may include neurons. Indeed ghrelin, induces neurogenesis and proliferation of neurons from the dorsal motor nucleus of the vagus [69-70], as well as neurogenesis in the spinal cord [71] and the nucleus of the solitary tract [72]. Furthermore, GHRP-6 treated diabetic rats had increased rIGF-I and IGF-I mRNA levels in the cerebellum compared to saline-treated rats, which suggests that GHRP-6 might induce proliferation through an IGF-I mediated mechanism. 


\section{CONCLUSIONS}

In conclusion insulin and GHRP-6 treatments exert different protective effects in the pituitary, hypothalamus and cerebellum of STZ-diabetic rats. These results could have clinical relevance as they show that insulin treatment, although it prevents most of diabetes-induced alterations in the pituitary, does not prevent some of the alterations occurring at different levels of the CNS. In contrast, the combination of insulin and GHRP-6 prevents some of diabetesinduced alterations in the hypothalamus and the cerebellum.

\section{ACKNOWLEDGEMENTS}

This work was funded by grants from Fondo de Investigación Sanitaria (PI070182), CIBER Fisiopatología de Obesidad y Nutrición (CIBEROBN) Instituto de Salud Carlos III and Fundación de Endocrinología y Nutrición. MG is supported by the Juan de la Cierva program from the Ministerio de Educacion y Ciencia. CG-C is supported by a predoctoral fellowship from the Ministerio de Educación y Ciencia (FPU AP2006/02761) and JAC is supported by the biomedical investigation program of the Consejería de Sanidad y Consumo de la Comunidad de Madrid. The authors would like to thank Sandra Canelles and Francisca Díaz for the excellent technical support.

\section{REFERENCES}

[1] Bestetti, G., Locatelli, V., Tirone, F., Rossi, G.L. and Müller, E.E. (1985) One month of streptozotocin-diabetes induces different neuroendocrine and morphological alterations in the hypothalamo-pituitary axis of male and female rats. Endocrinology 117, 208--216.

[2] Boujon, C.E., Bestetti, G.E., Abramo, F., Locatelli, V. and Rossi, G.L. (1995) The reduction of circulating growth hormone and prolactin in streptozocininduced diabetic male rats is possibly caused by hypothalamic rather than pituitary changes. J Endocrinol 145, 19--26.

[3] Välimäki, M., Liewendahl, K., Nikkanen, P. and Pelkonen, R. (1991) Hormonal changes in severely uncontrolled type 1 (insulin-dependent) diabetes mellitus. Scand J Clin Lab Invest 51, 385--393. 
[4] Fouyas, I.P., Kelly, P.A.T., Ritchie, I.M., Lammie, G.A. and Whittle, I.R. (2003) Cerebrovascular responses to pathophysiological insult in diabetic rats. J Clin Neurosci 10, 88--91.

[5] Manschot, S.M., Biessels, G.J., de Valk, H., Algra, A., Rutten, G.E.H.M., van der Grond, J., Kappelle, L.J. and Group, U.D.E.S. (2007) Metabolic and vascular determinants of impaired cognitive performance and abnormalities on brain magnetic resonance imaging in patients with type 2 diabetes. Diabetologia 50, 2388--2397.

[6] Valko, M., Leibfritz, D., Moncol, J., Cronin, M.T.D., Mazur, M. and Telser, J. (2007) Free radicals and antioxidants in normal physiological functions and human disease. Int J Biochem Cell Biol 39, 44--84.

[7] Jakobsen, J., Sidenius, P., Gundersen, H.J. and Osterby, R. (1987) Quantitative changes of cerebral neocortical structure in insulin-treated long-term streptozocin-induced diabetes in rats. Diabetes 36, 597--601.

[8] Klein, J.P., Hains, B.C., Craner, M.J., Black, J.A. and Waxman, S.G. (2004) Apoptosis of vasopressinergic hypothalamic neurons in chronic diabetes mellitus. Neurobiol Dis 15, 221--228.

[9] Li, Z.-G., Zhang, W., Grunberger, G. and Sima, A.A.F. (2002) Hippocampal neuronal apoptosis in type 1 diabetes. Brain Res 946, 221--231.

[10] Acheampong, E.A., Roschel, C., Mukhtar, M., Srinivasan, A., Rafi, M., Pomerantz, R.J. and Parveen, Z. (2009) Combined effects of hyperglycemic conditions and HIV-1 Nef: a potential model for induced HIV neuropathogenesis. Virol J 6, 183.

[11] García-Cáceres, C., Lechuga-Sancho, A., Argente, J., Frago, L.M. and Chowen, J.A. (2008) Death of hypothalamic astrocytes in poorly controlled diabetic rats is associated with nuclear translocation of apoptosis inducing factor. $\mathbf{J}$ Neuroendocrinol 20, 1348--1360.

[12] Lechuga-Sancho, A.M., Arroba, A.I., Frago, L.M., García-Cáceres, C., de Célix, A.D.-R., Argente, J. and Chowen, J.A. (2006) Reduction in the number of astrocytes and their projections is associated with increased synaptic protein density in the hypothalamus of poorly controlled diabetic rats. Endocrinology 147, 5314--5324.

[13] Lechuga-Sancho, A.M., Arroba, A.I., Frago, L.M., Pañeda, C., García-Cáceres, C., de Célix, A.D.R., Argente, J. and Chowen, J.A. (2006) Activation of the intrinsic cell death pathway, increased apoptosis and modulation of astrocytes in the cerebellum of diabetic rats. Neurobiol Dis 23, 290--299.

[14] Rungger-Brändle, E., Dosso, A.A. and Leuenberger, P.M. (2000) Glial reactivity, an early feature of diabetic retinopathy. Invest Ophthalmol Vis Sci 41, 1971--1980.

[15] Arroba, A.I., Frago, L.M., Argente, J. and Chowen, J.A. (2005) Activation of caspase 8 in the pituitaries of streptozotocin-induced diabetic rats: implication in increased apoptosis of lactotrophs. Endocrinology 146, 4417--4424.

[16] Arroba, A.I., Frago, L.M., Pañeda, C., Argente, J. and Chowen, J.A. (2003) The number of lactotrophs is reduced in the anterior pituitary of streptozotocininduced diabetic rats. Diabetologia 46, 634--638.

[17] Granado, M., Chowen, J.A., García-Cáceres, C., Delgado-Rubín, A., Barrios, V., Castillero, E., Argente, J. and Frago, L.M. (2009) Ghrelin treatment protects lactotrophs from apoptosis in the pituitary of diabetic rats. Mol Cell Endocrinol 309, 67--75. 
[18] Aschner, M. (2000) Neuron-astrocyte interactions: implications for cellular energetics and antioxidant levels. Neurotoxicology 21, 1101--1107.

[19] Lamigeon, C., Bellier, J.P., Sacchettoni, S., Rujano, M. and Jacquemont, B. (2001) Enhanced neuronal protection from oxidative stress by coculture with glutamic acid decarboxylase-expressing astrocytes. J Neurochem 77, 598--606.

[20] Montgomery, D.L. (1994) Astrocytes: form, functions, and roles in disease. Vet Pathol 31, 145--167.

[21] Biessels, G.J., Kamal, A., Urban, I.J., Spruijt, B.M., Erkelens, D.W. and Gispen, W.H. (1998) Water maze learning and hippocampal synaptic plasticity in streptozotocin-diabetic rats: effects of insulin treatment. Brain Res 800, 125-135.

[22] Pérez Díaz, J., Benitez, A. and C., F.G. (1982) Effect of streptozotocin diabetes on the pituitary-testicular axis in the rat. Horm Metab Res. 14(9), 479-82.

[23] Duarte, A.I., Santos, P., Oliveira, C.R., Santos, M.S. and Rego, A.C. (2008) Insulin neuroprotection against oxidative stress is mediated by Akt and GSK3beta signaling pathways and changes in protein expression. Biochim Biophys Acta 1783, 994--1002.

[24] Lee-Kwon, W., Park, D., Baskar, P.V., Kole, S. and Bernier, M. (1998) Antiapoptotic signaling by the insulin receptor in Chinese hamster ovary cells. Biochemistry 37, 15747--15757.

[25] Voll, C.L. and Auer, R.N. (1991) Insulin attenuates ischemic brain damage independent of its hypoglycemic effect. J Cereb Blood Flow Metab 11, 1006-1014.

[26] Voll, C.L. and Auer, R.N. (1991) Postischemic seizures and necrotizing ischemic brain damage: neuroprotective effect of postischemic diazepam and insulin. Neurology 41, 423--428.

[27] Bowers, C.Y., Momany, F.A., Reynolds, G.A. and Hong, A. (1984) On the in vitro and in vivo activity of a new synthetic hexapeptide that acts on the pituitary to specifically release growth hormone. Endocrinology 114, 1537-1545.

[28] Howard, A.D., Feighner, S.D., Cully, D.F., Arena, J.P., Liberator, P.A., Rosenblum, C.I., Hamelin, M., Hreniuk, D.L., Palyha, O.C., Anderson, J., Paress, P.S., Diaz, C., Chou, M., Liu, K.K., McKee, K.K., Pong, S.S., Chaung, L.Y., Elbrecht, A., Dashkevicz, M., Heavens, R., Rigby, M., Sirinathsinghji, D.J., Dean, D.C., Melillo, D.G., Patchett, A.A., Nargund, R., Griffin, P.R., DeMartino, J.A., Gupta, S.K., Schaeffer, J.M., Smith, R.G. and der Ploeg, L.H.V. (1996) A receptor in pituitary and hypothalamus that functions in growth hormone release. Science 273, 974--977.

[29] Wren, A.M., Seal, L.J., Cohen, M.A., Brynes, A.E., Frost, G.S., Murphy, K.G., Dhillo, W.S., Ghatei, M.A. and Bloom, S.R. (2001) Ghrelin enhances appetite and increases food intake in humans. J Clin Endocrinol Metab 86, 5992.

[30] Tschöp, M., Smiley, D.L. and Heiman, M.L. (2000) Ghrelin induces adiposity in rodents. Nature 407, 908--913.

[31] Dixit, V.D., Schaffer, E.M., Pyle, R.S., Collins, G.D., Sakthivel, S.K., Palaniappan, R., Lillard, J.W. and Taub, D.D. (2004) Ghrelin inhibits leptin- and activation-induced proinflammatory cytokine expression by human monocytes and T cells. J Clin Invest 114, 57--66.

[32] Granado, M., Priego, T., Martín, A.I., Villanúa, M.A. and López-Calderón, A. (2005) Anti-inflammatory effect of the ghrelin agonist growth hormone- 
releasing peptide-2 (GHRP-2) in arthritic rats. Am J Physiol Endocrinol Metab 288, E486--E492.

[33] Chung, H., Kim, E., Lee, D.H., Seo, S., Ju, S., Lee, D., Kim, H. and Park, S. (2007) Ghrelin inhibits apoptosis in hypothalamic neuronal cells during oxygenglucose deprivation. Endocrinology 148, 148--159.

[34] Granata, R., Settanni, F., Trovato, L., Destefanis, S., Gallo, D., Martinetti, M., Ghigo, E. and Muccioli, G. (2006) Unacylated as well as acylated ghrelin promotes cell survival and inhibit apoptosis in HIT-T15 pancreatic beta-cells. J Endocrinol Invest 29, RC19--RC22.

[35] Miao, Y., Xia, Q., Hou, Z., Zheng, Y., Pan, H. and Zhu, S. (2007) Ghrelin protects cortical neuron against focal ischemia/reperfusion in rats. Biochem Biophys Res Commun 359, 795--800.

[36] Delgado-Rubín, A., Chowen, J.A., Argente, J. and Frago, L.M. (2009) Growth hormone-releasing peptide 6 protection of hypothalamic neurons from glutamate excitotoxicity is caspase independent and not mediated by insulin-like growth factor I. Eur J Neurosci 29, 2115--2124.

[37] Pañeda, C., Arroba, A.I., Frago, L.M., Holm, A.M., Rømer, J., Argente, J. and Chowen, J.A. (2003) Growth hormone-releasing peptide-6 inhibits cerebellar cell death in aged rats. Neuroreport 14, 1633--1635.

[38] Frago, L.M., Pañeda, C., Dickson, S.L., Hewson, A.K., Argente, J. and Chowen, J.A. (2002) Growth hormone (GH) and GH-releasing peptide-6 increase brain insulin-like growth factor-I expression and activate intracellular signaling pathways involved in neuroprotection. Endocrinology 143, 4113--4122.

[39] Irako, T., Akamizu, T., Hosoda, H., Iwakura, H., Ariyasu, H., Tojo, K., Tajima, N. and Kangawa, K. (2006) Ghrelin prevents development of diabetes at adult age in streptozotocin-treated newborn rats. Diabetologia 49, 1264-73.

[40] Dezaki, K., Hosoda, H., Kakei, M., Hashiguchi, S., Watanabe, M., Kangawa, K. and Yada, T. (2004) Endogenous ghrelin in pancreatic islets restricts insulin release by attenuating $\mathrm{Ca} 2+$ signaling in beta-cells: implication in the glycemic control in rodents. Diabetes 53, 3142-3151.

[41] Granado, M., García-Cáceres, C., Frago, L.M., Argente, J. and Chowen, J.A. (2010) The positive effects of growth hormone-releasing peptide-6 on weight gain and fat mass accrual depend on the insulin/glucose status. Endocrinology 151, 2008-2018.

[42] Cibrián, D., Ajamieh, H., Berlanga, J., León, O.S., Alba, J.S., Kim, M.J.-T., Marchbank, T., Boyle, J.J., Freyre, F., Barco, D.G.D., Lopez-Saura, P., Guillen, G., Ghosh, S., Goodlad, R.A. and Playford, R.J. (2006) Use of growth-hormonereleasing peptide-6 (GHRP-6) for the prevention of multiple organ failure. Clin Sci (Lond) 110, 563--573.

[43] Granado, M., Priego, T., Martín, A.I., Villanúa, M.A. and López-Calderón, A. (2005) Ghrelin receptor agonist GHRP-2 prevents arthritis-induced increase in E3 ubiquitin-ligating enzymes MuRF1 and MAFbx gene expression in skeletal muscle. Am J Physiol Endocrinol Metab 289, E1007--E1014.

[44] Winter, B.Y.D., Man, J.G.D., Seerden, T.C., Depoortere, I., Herman, A.G., Peeters, T.L. and Pelckmans, P.A. (2004) Effect of ghrelin and growth hormonereleasing peptide 6 on septic ileus in mice. Neurogastroenterol Motil 16, 439-446.

[45] Livak, K.J. and Schmittgen, T.D. (2001) Analysis of relative gene expression data using real-time quantitative PCR and the 2(-Delta Delta C(T)) Method. Methods 25, 402--408. 
[46] Granado, M., García-Cáceres, C., Frago, L.M., Argente, J. and Chowen, J.A. (2010) The positive effects of growth hormone-releasing peptide-6 on weight gain and fat mass accrual depend on the insulin/glucose status. Endocrinology 151, 2008--2018.

[47] Grünblatt, E., Salkovic-Petrisic, M., Osmanovic, J., Riederer, P. and Hoyer, S. (2007) Brain insulin system dysfunction in streptozotocin intracerebroventricularly treated rats generates hyperphosphorylated tau protein. J Neurochem 101, 757--770.

[48] Peeyush, K.T., Gireesh, G., Jobin, M. and Paulose, C.S. (2009) Neuroprotective role of curcumin in the cerebellum of streptozotocin-induced diabetic rats. Life Sci 85, 704--710.

[49] Park, S., ding Peng, X., Frohman, L.A. and Kineman, R.D. (2005) Expression analysis of hypothalamic and pituitary components of the growth hormone axis in fasted and streptozotocin-treated neuropeptide Y (NPY)-intact (NPY+/+) and NPY-knockout (NPY-/-) mice. Neuroendocrinology 81, 360--371.

[50] Yamashita, S. and Melmed, S. (1986) Effects of insulin on rat anterior pituitary cells. Inhibition of growth hormone secretion and mRNA levels. Diabetes 35, 440--447.

[51] Olchovsky, D., Bruno, J.F., Gelato, M.C., Song, J. and Berelowitz, M. (1991) Pituitary insulin-like growth factor-I content and gene expression in the streptozotocin-diabetic rat: evidence for tissue-specific regulation. Endocrinology 128, 923--928.

[52] Bestetti, G.E., Boujon, C.E., Reymond, M.J. and Rossi, G.L. (1989) Functional and morphological changes in mediobasal hypothalamus of streptozocin-induced diabetic rats. In vitro study of LHRH release. Diabetes 38, 471--476.

[53] Pitton, I., Bestetti, G.E. and Rossi, G.L. (1987) The changes in the hypothalamopituitary-gonadal axis of streptozotocin-treated male rats depend from age at diabetes onset. Andrologia 19, 464--473.

[54] Rossi, G.L. and Bestetti, G. (1981) Morphological changes in the hypothalamichypophyseal-gonadal axis of male rats after twelve months of streptozotocininduced diabetes. Diabetologia 21, 476--481.

[55] Bestetti, G.E., Barone, D., Walz, A., Moser, B., Boujon, C.E., Brändli-Baiocco, A. and Rossi, G.L. (1997) LHRH receptors and LHRH receptor-bearing cells in pituitaries of streptozocin diabetic male rats. Pharmacol Res 35, 321--327.

[56] Garibay, M.A.P., Monsalve, C.R., Sánchez, A.C., Ponce, A.C.P. and Andrade, S.I. (1998) [Effect of induced diabetes on reproduction and development]. Ginecol Obstet Mex 66, 403--406.

[57] Baldanzi, G., Filigheddu, N., Cutrupi, S., Catapano, F., Bonissoni, S., Fubini, A., Malan, D., Baj, G., Granata, R., Broglio, F., Papotti, M., Surico, N., Bussolino, F., Isgaard, J., Deghenghi, R., Sinigaglia, F., Prat, M., Muccioli, G., Ghigo, E. and Graziani, A. (2002) Ghrelin and des-acyl ghrelin inhibit cell death in cardiomyocytes and endothelial cells through ERK1/2 and PI 3-kinase/AKT. J Cell Biol 159, 1029--1037.

[58] Filigheddu, N., Gnocchi, V.F., Coscia, M., Cappelli, M., Porporato, P.E., Taulli, R., Traini, S., Baldanzi, G., Chianale, F., Cutrupi, S., Arnoletti, E., Ghè, C., Fubini, A., Surico, N., Sinigaglia, F., Ponzetto, C., Muccioli, G., Crepaldi, T. and Graziani, A. (2007) Ghrelin and des-acyl ghrelin promote differentiation and fusion of C2C12 skeletal muscle cells. Mol Biol Cell 18, 986--994.

[59] Granata, R., Settanni, F., Biancone, L., Trovato, L., Nano, R., Bertuzzi, F., Destefanis, S., Annunziata, M., Martinetti, M., Catapano, F., Ghè, C., Isgaard, J., 
Papotti, M., Ghigo, E. and Muccioli, G. (2007) Acylated and unacylated ghrelin promote proliferation and inhibit apoptosis of pancreatic beta-cells and human islets: involvement of 3',5'-cyclic adenosine monophosphate/protein kinase A, extracellular signal-regulated kinase 1/2, and phosphatidyl inositol 3-Kinase/Akt signaling. Endocrinology 148, 512--529.

[60] Aizenman, Y. and de Vellis, J. (1987) Synergistic action of thyroid hormone, insulin and hydrocortisone on astrocyte differentiation. Brain Res 414, 301--308.

[61] Avola, R., Tullio, M.A.D., Fisichella, A., Tayebati, S.K. and Tomassoni, D. (2004) Glial fibrillary acidic protein and vimentin expression is regulated by glucocorticoids and neurotrophic factors in primary rat astroglial cultures. Clin Exp Hypertens 26, 323--333.

[62] Bramanti, V., Bronzi, D., Raciti, G., Avitabile, M. and Avola, R. (2007) Neurosteroid-growth factor cross-talk induces up and down regulation of GFAP and vimentin expression in serum free astrocyte cultures. Ital J Biochem 56, 302--306.

[63] Bramanti, V., Campisi, A., Tomassoni, D., Costa, A., Fisichella, A., Mazzone, V., Denaro, L., Avitabile, M., Amenta, F. and Avola, R. (2007) Astroglialconditioned media and growth factors modulate proliferation and differentiation of astrocytes in primary culture. Neurochem Res 32, 49--56.

[64] Matsuda, T., Murata, Y., Tanaka, K., Hosoi, R., Hayashi, M., Tamada, K., Takuma, K. and Baba, A. (1996) Involvement of $\mathrm{Na}+\mathrm{K}(+)$ ATPase in the mitogenic effect of insulin-like growth factor-I on cultured rat astrocytes. J Neurochem 66, 511--516.

[65] Horvath, T.L., Sarman, B., García-Cáceres, C., Enriori, P.J., Sotonyi, P., Shanabrough, M., Borok, E., Argente, J., Chowen, J.A., Perez-Tilve, D., Pfluger, P.T., Brönneke, H.S., Levin, B.E., Diano, S., Cowley, M.A. and Tschöp, M.H. (2010) Synaptic input organization of the melanocortin system predicts dietinduced hypothalamic reactive gliosis and obesity. Proc Natl Acad Sci U S A 107, 14875--14880.

[66] Hsuchou, H., He, Y., Kastin, A.J., Tu, H., Markadakis, E.N., Rogers, R.C., Fossier, P.B. and Pan, W. (2009) Obesity induces functional astrocytic leptin receptors in hypothalamus. Brain 132, 889--902.

[67] Coleman, E., Judd, R., Hoe, L., Dennis, J. and Posner, P. (2004) Effects of diabetes mellitus on astrocyte GFAP and glutamate transporters in the CNS. Glia 48, 166--178.

[68] Coleman, E.S., Dennis, J.C., Braden, T.D., Judd, R.L. and Posner, P. (2010) Insulin treatment prevents diabetes-induced alterations in astrocyte glutamate uptake and GFAP content in rats at 4 and 8 weeks of diabetes duration. Brain Res 1306, 131--141.

[69] Ammori, J.B., Zhang, W.-Z., Li, J.-Y., Chai, B.-X. and Mulholland, M.W. (2008) Effects of ghrelin on neuronal survival in cells derived from dorsal motor nucleus of the vagus. Surgery 144, 159--167.

[70] Zhang, W., Lin, T.R., Hu, Y., Fan, Y., Zhao, L., Stuenkel, E.L. and Mulholland, M.W. (2004) Ghrelin stimulates neurogenesis in the dorsal motor nucleus of the vagus. J Physiol 559, 729--737.

[71] Sato, M., Nakahara, K., Goto, S., Kaiya, H., Miyazato, M., Date, Y., Nakazato, M., Kangawa, K. and Murakami, N. (2006) Effects of ghrelin and des-acyl ghrelin on neurogenesis of the rat fetal spinal cord. Biochem Biophys Res Commun 350, 598--603. 
[72] Zhang, W., Hu, Y., Lin, T.R., Fan, Y. and Mulholland, M.W. (2005) Stimulation of neurogenesis in rat nucleus of the solitary tract by ghrelin. Peptides 26, 2280-2288. 


\section{FIGURE LEGENDS}

\section{Table 1}

Western Blot antibodies

\section{Table 2}

Gene expression of growth hormone $(\mathrm{GH})$, prolactin (PRL), pro-opiomelanocortin (POMC), thyroid- stimulating hormone (TSH), luteinizing hormone (LH) and follicle-stimulating hormone $(\mathrm{FSH})$ in the pituitary of control rats injected with saline $(\mathrm{C}+\mathrm{SALINE})$ and diabetic rats injected with saline (DB+SALINE), growth hormone-releasing peptide 6 (GHRP-6 (DB+GHRP6, $150 \mu \mathrm{g} / \mathrm{kg} / \mathrm{day}$ ), insulin (DB+INS, 0-8 U/day) or insulin plus GHRP-6 (DB+INS+GHRP-6). Data are presented as mean \pm SEM and referred to control values $(n=4-6){ }^{*}=p$ value is lower than 0.05 .

\section{Figure 1}

Cell death (A), total protein content (B) and proliferating cell nuclear antigen (PCNA) levels (C) in the pituitary of control rats injected with saline (C+SALINE) and diabetic rats injected with saline (DB+SALINE), growth hormone-releasing peptide 6 (GHRP-6 (DB+GHRP6, $150 \mu \mathrm{g} / \mathrm{kg} /$ day), insulin (DB+INS, 0-8 U/day) or insulin plus GHRP-6 (DB+INS+GHRP-6). Data are presented as mean \pm SEM and referred to control values $(n=4-6){ }^{*}=p$ value is lower than 0.05 .

\section{Figure 2}

Pituitary levels of B-cell lymphoma 2 (Bcl-2; A), heat shock protein-70 (Hsp-70; B) and X-linked inhibitor of apoptosis protein (XIAP) $30 \mathrm{kDa}(\mathrm{C})$ in control rats injected with saline $(\mathrm{C}+\mathrm{SALINE})$ and diabetic rats injected with saline (DB+SALINE), growth hormone-releasing 
peptide 6 (GHRP-6 (DB+GHRP-6, $150 \mu \mathrm{g} / \mathrm{kg} /$ day), insulin (DB+INS, 0-8 U/day) or insulin plus GHRP-6 (DB+INS+GHRP-6). Data are presented as mean \pm SEM and referred to control values $(\mathrm{n}=4-6) . * \mathrm{p}$ value is lower than 0.05 .

\section{Figure 3}

Active caspase-8 (A) and tumor necrosis factor $\alpha$ (TNF- $\alpha$ ) mRNA levels (B) in the pituitary of control rats injected with saline $(\mathrm{C}+\mathrm{SALINE})$ and diabetic rats injected with saline (DB+SALINE), growth hormone-releasing peptide 6 (GHRP-6 (DB+GHRP-6, $150 \mu \mathrm{g} / \mathrm{kg} / \mathrm{day})$, insulin (DB+INS, 0-8 U/day) or insulin plus GHRP-6 (DB+INS+GHRP-6). Data are presented as mean \pm SEM and referred to control values $(n=4-6) . *=p$ value is lower than 0.05 .

\section{Figure 4}

Insulin-like growth factor I (IGF-I; A) and IGF-I receptor (rIGF-I; B) mRNA levels in the pituitary of control rats injected with saline $(\mathrm{C}+\mathrm{SALINE})$ and diabetic rats injected with saline (DB+SALINE), growth hormone-releasing peptide 6 (GHRP-6 (DB+GHRP-6, $150 \mu \mathrm{g} / \mathrm{kg} / \mathrm{day}$ ), insulin (DB+INS, 0-8 U/day) or insulin plus GHRP-6 (DB+INS+GHRP-6). Data are presented as mean \pm SEM and referred to control values $(n=4-6) . *=p$ value is lower than 0.05 .

\section{Figure 5}

Cell death (A), proliferating cell nuclear antigen (PCNA; B) and glial fibrillary acidic protein (GFAP; C) levels in the hypothalamus of control rats injected with saline (C+SALINE) and diabetic rats injected with saline (DB+SALINE), growth hormone-releasing peptide 6 (GHRP-6 (DB+GHRP-6, $150 \mu \mathrm{g} / \mathrm{kg} / \mathrm{day}$ ), insulin (DB+INS, 0-8 U/day) or insulin plus GHRP-6 $(\mathrm{DB}+\mathrm{INS}+\mathrm{GHRP}-6)$. Data are presented as mean \pm SEM and referred to control values $(\mathrm{n}=4-6)$. $*=\mathrm{p}$ value is lower than 0.05 . 


\section{Figure 6}

Insulin-like growth factor I (IGF-I; A) and IGF-I receptor (rIGF-I; B) mRNA levels in the hypothalamus of control rats injected with saline (C+SALINE) and diabetic rats injected with saline (DB+SALINE), growth hormone-releasing peptide 6 (GHRP-6 (DB+GHRP-6, 150 $\mu \mathrm{g} / \mathrm{kg} /$ day), insulin (DB+INS, 0-8 U/day) or insulin plus GHRP-6 (DB+INS+GHRP-6). Data are presented as mean \pm SEM and referred to control values $(n=4-6) . *=p$ value is lower than 0.05 .

\section{Figure 7}

Cell death (A), proliferating cell nuclear antigen (PCNA) (B) and glial fibrillary acidic protein (GFAP) content $(\mathrm{C})$ in the cerebellum of control rats injected with saline (C+SALINE) and diabetic rats injected with saline (DB+SALINE), growth hormone-releasing peptide 6 (GHRP-6 (DB+GHRP-6, $150 \mu \mathrm{g} / \mathrm{kg} /$ day), insulin (DB+INS, 0-8 U/day) or insulin plus GHRP-6 $(\mathrm{DB}+\mathrm{INS}+\mathrm{GHRP}-6)$. Data are presented as mean \pm SEM and referred to control values $(\mathrm{n}=4-6)$. $*=\mathrm{p}$ value is lower than 0.05 .

\section{Figure 8}

Active caspase 9 (A), caspase 6 (B) and caspase 3 (C) levels in the cerebellum of control rats injected with saline (C+SALINE) and diabetic rats injected with saline (DB+SALINE), growth hormone-releasing peptide 6 (GHRP-6 (DB+GHRP-6, $150 \mu \mathrm{g} / \mathrm{kg} / \mathrm{day})$, insulin (DB+INS, 0-8 U/day) or insulin plus GHRP-6 (DB+INS+GHRP-6). Data are presented as mean \pm SEM and referred to control values $(\mathrm{n}=4-6) . *$ v value is lower than 0.05 .

\section{Figure 9}

Insulin-like growth factor I (IGF-I) (A) and IGF-I receptor (rIGF-I; B) mRNA levels in the cerebellum of control rats injected with saline (C+SALINE) and diabetic rats injected with 
saline (DB+SALINE), growth hormone-releasing peptide 6 (GHRP-6 (DB+GHRP-6, 150 $\mu \mathrm{g} / \mathrm{kg} /$ day), insulin (DB+INS, 0-8 U/day) or insulin plus GHRP-6 (DB+INS+GHRP-6). Data are presented as mean \pm SEM and referred to control values $(n=4-6){ }^{*}=p$ value is lower than 0.05 . 

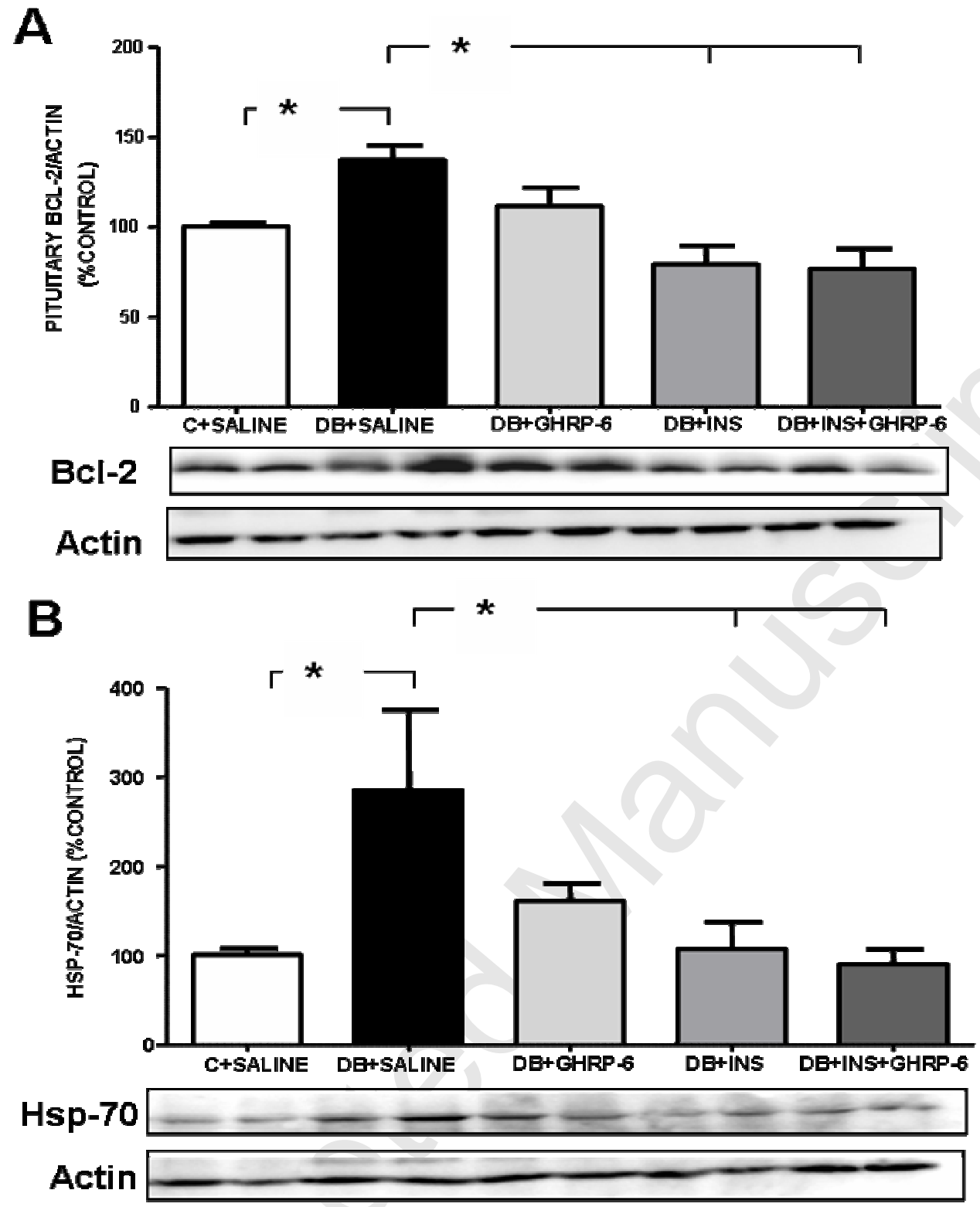

C

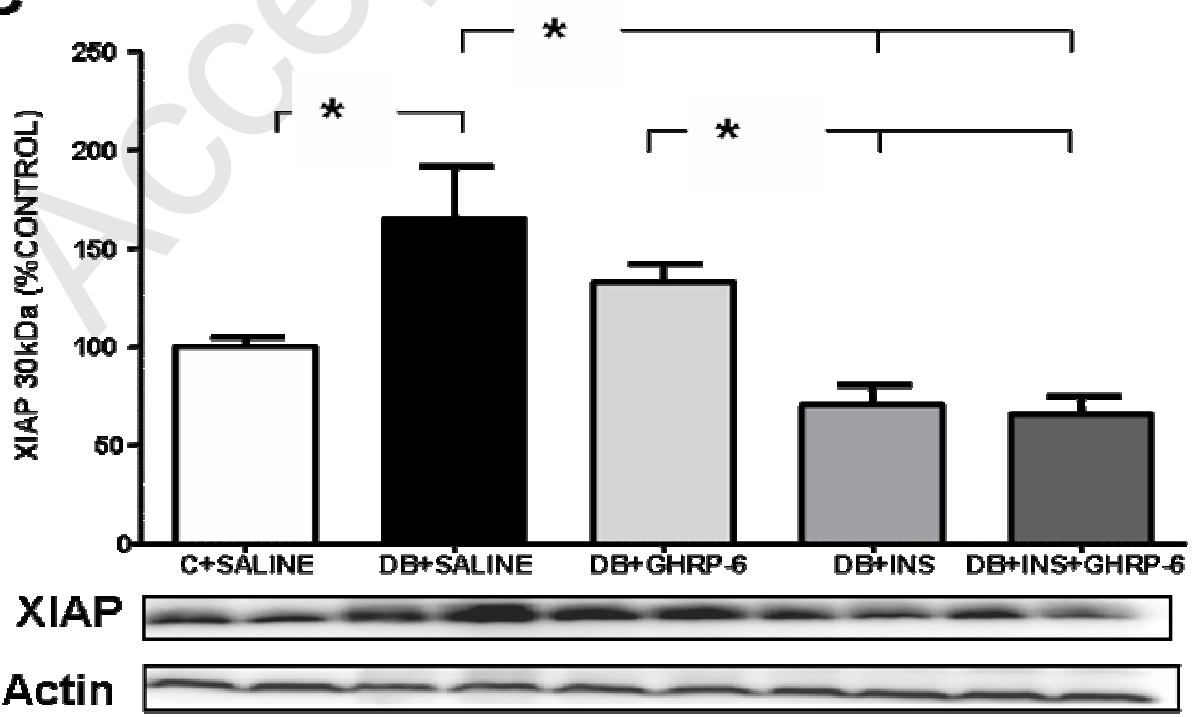



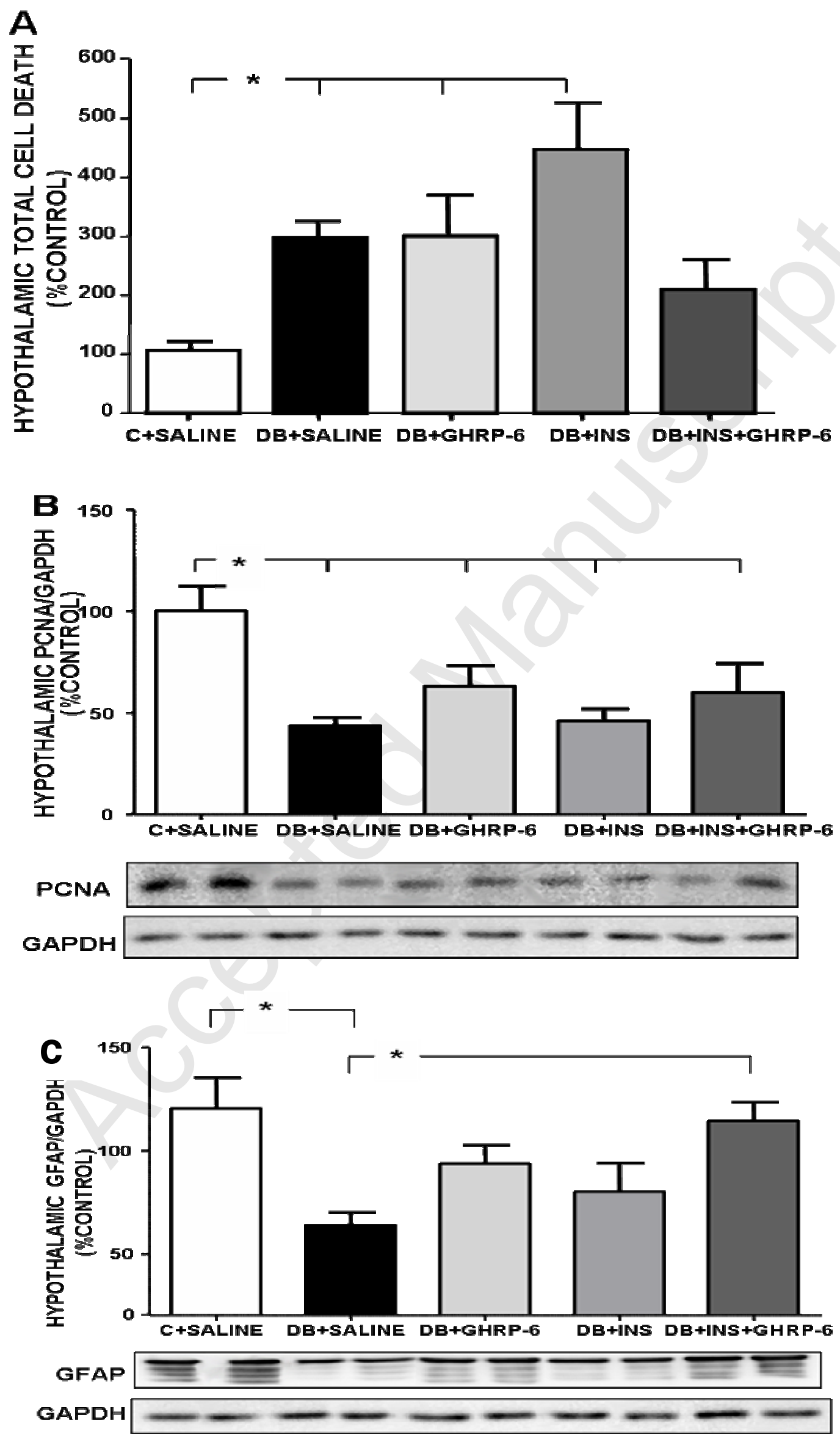


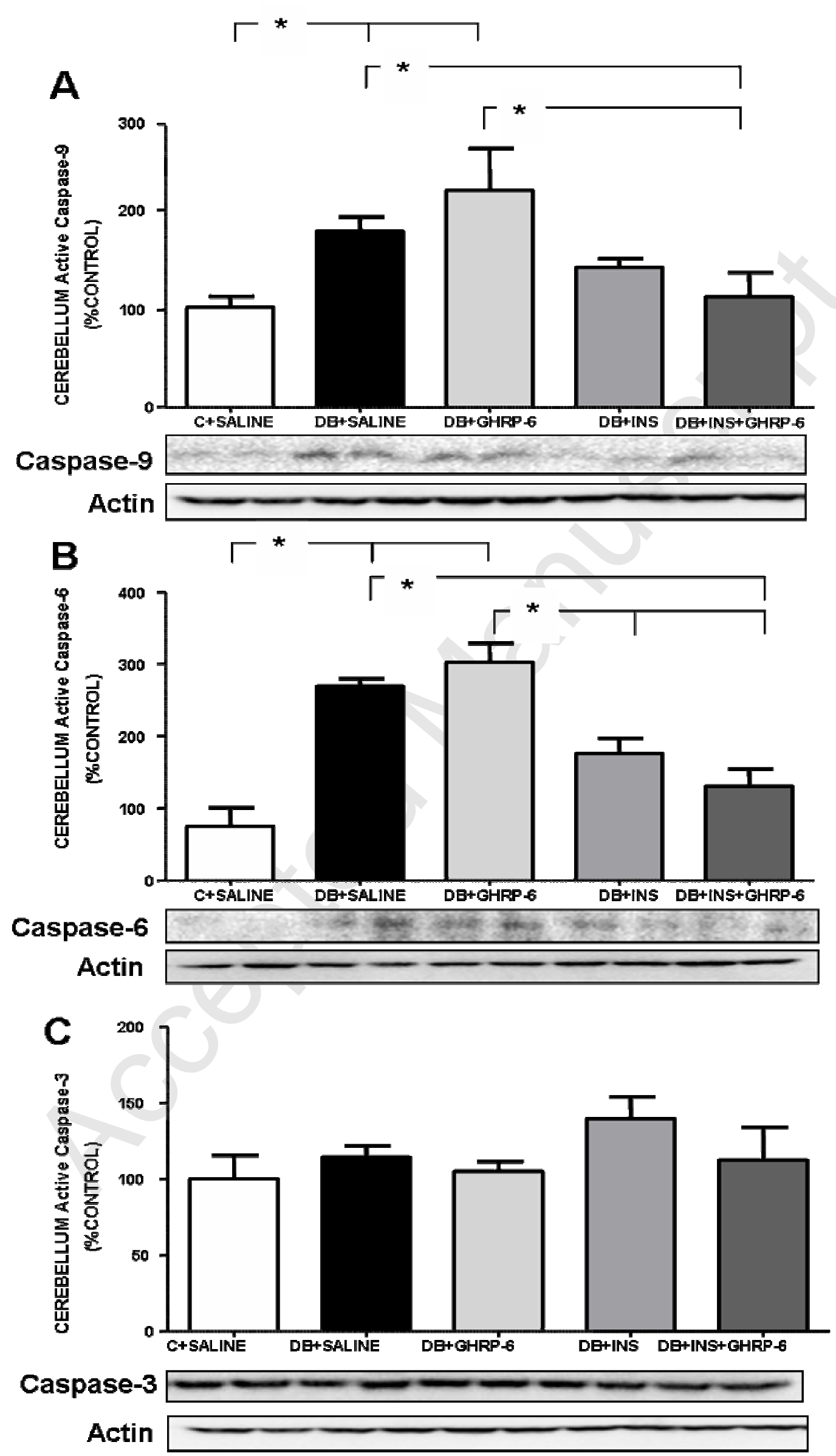

